\title{
DECIDING DISPUTES: FACTORS THAT GUIDE CHINESE COURTS IN THE ADJUDICATION OF RURAL RESPONSIBILITY CONTRACT DISPUTES
}

\author{
Phyllis L. Chang* \\ INTRODUCTION
}

Judicial resolution of economic contract disputes in the People's Republic of China ("PRC") has become an increasingly common phenomenon. ${ }^{1}$ This growth in litigation mandates new attention to the role of courts in the resolution of commercial disputes in Chinese society. A paucity of information on the function and workings of Chinese courts presently exists; in recent years, foreign scholars of Chinese law have devoted most of their energies to exegesis of new legislation rather than analysis of the institutions, processes, and individual actors that constitute the emerging Chinese legal system.

The adjudication ${ }^{2}$ process itself deserves study. Little is known, for example, about the working relationships among various levels of courts, the supervisory role played by the Supreme People's Court, the coordination of the courts with the procuracy, or the interaction of disputants, judges, and lawyers during a case. And although research into procedural practice-not simply procedural rules-can be of only limited scope for foreign researchers

\footnotetext{
Copyright $(1989$ by Law and Contemporary Problems

* Associate, Thelen, Marrin, Johnson \& Bridges, San Francisco. Much of the research for this paper was conducted in 1985-86 while the author was a visiting graduate student in the Law Department of People's University, Beijing. The author would like to thank the People's University Law Department and Thelen Marrin for their support, as well as Ms. Yu Muhua, indefatigable negotiator and assistant during the field work conducted for this paper.

1. In 1986, 320,000 economic disputes were accepted by Chinese courts, up $42 \%$ from the 1985 figure. Economic contract disputes accounted for over $90 \%$ of all economic disputes. See Zheng, Work Report of the Supreme People's Court, Bulletin of the Supreme People's Court, No. 2 (1987)

2. "Adjudication" is used here in a broad sense. Strictly speaking, adjudication is the judicial determination of a controversy and the rendering of a judgment. For our purposes, however, adjudication encompasses not only court decisionmaking that results in a judgment, but also court action that leads to a settlement between parties. As a reading of any of the collections of civil cases that have appeared in the last several years shows, the great majority of civil disputes brought before Chinese courts are eventually settled through court mediation.
} 
at this time, the procedural aspects of litigation certainly warrant examination. ${ }^{3}$

Central to an understanding of the adjudication process is the issue of what norms courts apply when deciding or mediating disputes. The prototypical model of courts assumes that judges apply pre-existing legal rules in arriving at their decisions. ${ }^{4}$ Specifically, these legal rules are laws, administrative regulations, and, in common law courts, case law. However, at least in the field of economic contracts, Chinese courts have tried and decided conflicts without reference to laws and regulations, thereby suggesting that other norms or guidelines may shape judicial decisionmaking. ${ }^{5}$ This paper attempts to determine what norms and other factors, legal or non-legal, have guided courts in one particular type of economic contract dispute: rural production responsibility contract (nongcun chengbao hetong) disputes. First accepted by courts in 1982, by 1985 such disputes accounted for over 10 percent of economic disputes tried by Chinese courts. ${ }^{6}$

Part I of the article introduces rural responsibility contracts, summarizes the policy and law framework surrounding them, and describes the causes of responsibility contract disputes. In addition, it reviews the courts' gradual recognition of the contracts as legally enforceable agreements and notes how administrative resolution of disputes is far more common than adjudication. Part II analyzes the norms and guidelines that have influenced court resolution-whether through mediation or the rendering of a judgment-of the disputes.

3. Analyses of civil procedure issues based on actual cases have begun to appear in China. See, e.g., Zhou et al., Analysis of Civil Procedure Case Studies (1988). Though many Chinese lawyers privately acknowledge that courts often do not adhere strictly to procedural rules, it is also evident that higher courts have overturned lower court decisions for procedural violations; future studies will need to determine what type of procedural violations are considered serious enough to warrant annulment of a decision.

4. See generally M. Shapiro, Courts: A Comparative and Polirical Analysis (1981). Shapiro uses a comparative law analysis to argue that there are few, if any, courts in the world that fit the standard prototype which assumes courts are characterized by four features: (1) an independent judge (2) who applies pre-existing legal norms (3) in adversarial proceedings and (4) renders a "winner-take-all" decision in which one party is adjudged to be clearly wrong and the other right.

5. See, e.g., the economic contract cases analyzed in Macneil, Contract in China: Law, Practice, and Dispute Resolution, 38 Stan. L. REv. 303 (1986); these cases were decided by courts before the Economic Contract Law of the People's Republic of China ("the Economic Contract Law") took effect in July 1982. Macneil lists five "sources of law" that guided court resolution of the disputes: the contractual relationship itself, general contract principles, administrative regulations, custom and course of dealing, and ideology and the public interest. See id. at 334-348. Only one-fourth of the cases cited administrative regulations; the majority of the cases did not refer, at least explicitly, to promulgated legal rules. Macneil's focus, however, is not on these sources of law but on certain broader "contract norms" which, he says, underlie Chinese contractual relations. See id. at 338-389.

6. According to knowledgeable sources, the number of responsibility contract disputes grew steadily between 1982 and 1985, but declined after 1985 as collectives and peasants gained experience in drafting contracts and setting appropriate contract fees. In addition, in some localities where incomes from sideline production of products such as fruit or vegetables were very high, collectives re-adopted cooperative arrangements. 
II

\section{Rural Production Responsibility Contracts and Dispute RESOLUTION}

\section{A. Rural Responsibility Contracts: A Background}

Rural production responsibility contracts are the product of the rural decollectivization reform initiated by Deng Xiaoping in 1978-79. The reform, the success of which enabled the Chinese leader to launch other ambitious reforms of the economy, sought to spur agricultural production by introducing "production-linked contract responsibility systems" (lianchan chengbao zerenzhi), which decentralized control over production and linked compensation of an individual to his or her productivity. Numerous variants of production responsibility systems were introduced by rural cadres during the initial years of the reform. ${ }^{7}$

By late 1983, however, one type had become standard throughout the country: "full responsibility contracting to the household" (baogan dao hu). Under the system of full responsibility contracting to the household, commonly called the household responsibility system, peasant households contract with their collectives to assume full responsibility for the management of a parcel of the collective's land. The collective's role in production is reduced to technical assistance and sale or supply of seed, fertilizer, and other production inputs to households. In return for the right to farm the collective's land, households agree to sell a specified amount of grain or other products subject to contract procurement obligations ${ }^{8}$ to state purchasing organs, to pay the state agricultural tax, and to pay to the collective certain collective "dues" or fees-contributions to the collective's public welfare fund, public capital accumulation fund, and sometimes a "management fee" (guanli fei), covering miscellaneous collective expenses such as subsidies for local level cadres and office supplies. Once these

7. For a summary of the various types of contracts, see Kueh, The Economics of the "Second Land Reform" in China, China Q. 122 (No. 101, 1985).

8. The former compulsory procurement system under which rural collectives were required to sell to the state quotas of the four major farm products-grain, cotton, velvet, and vegetable oil crops-and quotas of other agricultural products (so-called "sideline production"), as well as surplus production, was abolished in 1985 and replaced by a contract procurement system (hetong dinggouzhi). In theory, under the contract system, which is meant to bring market forces into play in agricultural production, individual producers or collectives voluntarily contract with the state (through state purchasing units at local levels) to sell grain and staple crops to the state; surpluses may be sold on the free market. In fact, the former compulsory quotas have been largely preserved, for there is little or no bargaining between individual producers and the state. Typically, production quotas assigned to a province are broken down at successively lower administrative levels until the individual producer is assigned a production obligation. The break-downs are made on the basis of past production history with possible adjustment for any anticipated declines or increases. Purchase contracts usually are signed by village level administrative units rather than by producer households. Thus, households must meet what are essentially mandatory administrative quotas for grain and certain other agricultural products which remain subject to the state plan. In the case of sideline products, such as fruits, vegetables, and tea, decontrol has proceeded further. Farmers do not have to sign purchase contracts with state purchasing departments at all, but may sell to other commercial organizations at free market prices. 
obligations are met, households are allowed to keep any surplus production; in most households, a portion of the surplus is stocked for personal consumption or feed use, and the rest sold on the open market or to the state at higher, above quota prices.

Full responsibility contracting has not been limited to grain and staple crop land. Specialized production resources of collectives such as fruit orchards, fish ponds, animal breeding facilities, and brick kilns and other manufacturing or processing operations have also been contracted out to households. Contracts for the management of these types of resources are sometimes referred to as "specialized contracts," (zhuanye chengbao hetong). They stand in contrast to general or "comprehensive" land contracts (zonghexing tudi chengbao hetong), the ubiquitous ${ }^{9}$ contracts between collectives and households for the management of collectives' grain and staple crop land under which the household plants and harvests a number of different crops in accordance with the state procurement quotas their collective must meet. Households signing specialized contracts are termed "specialized households" (zhuanyehu). ${ }^{10}$

Under specialized contracts, households' obligations to the collective are simpler than in general land contracts: Households usually need pay the collective only a cash "contract fee" (chengbao fei). ${ }^{11}$ Households thus can retain all of their production. Some specialized contracts for larger-scale operations-such as contracts for the management of collective-owned factories-do require the contracting party to reach a target production figure; a penalty is imposed for failing to meet the target, or, if the target is exceeded, the contracting party and collective divide profits from the surplus production according to a stipulated ratio.

Many, but not all, rural responsibility contracts are in written form. Early Party documents sanctioning the use of output responsibility systems did not call on teams to sign contracts with peasants, ${ }^{12}$ but written contracts nonetheless appeared shortly after the introduction of responsibility systems, apparently to alleviate peasants' fears that their newly granted production autonomy would be stripped away should "policy change." 13 No single

9. With the possible exception of a small number of households which in recent years have "left the land," all households in a village will hold a comprehensive land contract. By contrast, only a handful of households will be party to a specialized contract; specialized resources are not distributed through an egalitarian formula, as is collective land, but contracted out through either an open bidding process or the selection of appropriate contracting households (or groups or individuals) by collective leaders.

10. "Specialized households" refer to rural households which devote most of their labor to the specialized production of a product or management of an operation and which sell rather than consume most of their output. Households that undertake specialized responsibility contracts are one type of specialized household; the other is the household that independently sets up shop. See Du, The Reform of China's Rural Economy 25 n.9 (1985).

11. Occasionally, the contract fee will be a payment in kind. Some contracts require payment of a cash fee plus sale at a preferential rate or donation to the collective of a certain amount of the specialized product for personal consumption by collective families.

12. These documents are listed in notes 21 and 22 infra; see also text accompanying notes 21-26.

13. See Qian, Information on Rurual Responsibility Contracts 8 (1986). See also Chen \& Zhong, Promote the Contract System to Carry Out the Production Responsibility System, in 5 RURAL Work 
standardized format for contracts, either land or specialized, has been developed. Rather, depending on the level of sophistication of local agricultural cadres and peasants and on available resources, contracts range in form from very simple to detailed, with specialized contracts usually more complex than general land contracts. For general land contracts, some degree of standardization has occurred as many township governments or counties have printed and issued contract forms that are used by all local villages. ${ }^{14}$ In contrast, specialized contracts are usually drafted by village cadres who often use one format for all contracts pertaining to a given type of resource. Thus, within a village, contracts for apple orchards may differ in form and substance from contracts for small-scale processing factories in the village, but all the orchard contracts are likely to be very similar in both form and content.

Even as notarization of contracts is gaining in popularity, ${ }^{15}$ oral contracts are still frequently encountered. As discussed below, courts may decide to enforce an oral contract. Notarization (gongzheng), which should not be confused with certification (jianzheng), or the official authorization to enter into a contract that is granted by an organ with supervisory authority over the unit signing the contract, is optional and ordinarily used for specialized contracts involving major undertakings. For example, contracts for the management of township factories commonly employ notarization. Generally requested by the party assuming management responsibility as a safeguard against contract disputes, notarization does not guarantee that the contract will be upheld in court; but courts are more willing to uphold and strictly enforce the terms of notarized contracts than unnotarized ones. ${ }^{16}$

\section{B. Causes of Responsibility Contract Disputes}

Most of the responsibility contract disputes reported in the press and law journals and discussed in this article have arisen over specialized contracts

Bulletin 24 (1981), and Zheng, Conscientiously Sign and Perform Responsibility Contracts, 3 Rural Work BULLETIN 24 (1982).

14. In some areas, written general land contracts have evolved from crude documents, to elaborate booklets that incorporate a wealth of administrative detail, back to simple one- or two-page agreements.

15. Rural officials interviewed were unable to provide any statistics on the percentage of specialized contracts that have been notarized. They reported, however, that the notary public's services were increasingly in demand and that notarization of contracts was not regarded as unusual. The role of the Chinese notary public is similar to the function of notaries in Continental law systems and extends beyond the simple duties of the American notary. For example. Chinese notary officials will review contracts for completeness, clarity, and legality. They will also check the credentials of parties to the contract to verify that they have the legal authority to enter into the contract. For a review of the re-emerging functions of Chinese notaries, see Chen, The Chinese Notariat: An Overlooked Cornerstone of the Legal System of the People's Republic of China, 35 INT'L \& Comp. L.Q. 63 (1986).

16. Zweig et al. state that notarization is essential for any claimant in a dispute who seeks to establish the binding force of a contract. See Zweig et al., Law, Contracts, and Economic Modernization: Lessons from the Recent Chinese Rural Reforms, 23 STAN. J. INT'L L. 319, 329 (1987); but both judicial officials and agricultural officials interviewed by the author asserted that notarization, while desirable and generally encouraged, was not essential for a contract to have binding force. Judges stated that notarization would, however, help convince the court that the contract had been formed legitimately and was legal. 
rather than general land contracts. Land contracts have rarely led to disputes for several reasons. First, barring natural disasters, households have not experienced difficulties in fulfilling their production obligations. These production quotas usually claim only a portion of the total harvest they have been reaping from their contracted land. Second, low prices of grain and the egalitarian distribution of contract land generate limited profits, thereby minimizing feelings of envy or inequality among households. Third, arguments over contract interpretation are very rare because contracts are highly standardized and in recent years increasingly simple. Finally, and most fundamentally, peasants appear to regard general land contracts as essentially the formalization of administrative decisions made by village or team leaders rather than legal pacts creating legally enforceable rights and duties. This view of the contracts renders peasants willing to accept leaders' proposals to modify contracts, especially if the proposed changes would affect all households similarly. This view explains why extremely few land contract disputes are brought before courts.

In contrast, disputes over specialized contracts have not been uncommon and have been appearing in courts regularly since the early 1980's. Unlike general land contracts, many specialized contracts offer the potential for large profits: Prices for specialized agricultural products such as fruit and fish have sharply increased after being decontrolled, while contract fees have been modest, largely because collectives have tended to underestimate the profitability of specialized resources. As the contracts negotiated in the early and mid-1980's expire, collectives will certainly drive a much harder bargain in the new contracts, either by boosting contract fees or shifting to a profitsharing system under which the collective is guaranteed a certain percentage of profits. However, under the early contracts, many households have netted large profits, and unbridled envy has sometimes driven collective leaders to terminate or modify the terms of contracts unilaterally; in some cases, peasants, upset at a fellow villager's success, have sabotaged manufacturing operations or stolen produce or animals. Such actions have prompted peasants to sue their collectives for breach of contract or interference with the contract.

Conversely, conflicts have also been caused by households failing to fulfill their contract duties; for specialized contracts are far more economically risky than land contracts: Product prices are subject to market fluctuations, significant capital investment is often necessary, and successful production requires a higher level of technical skill. In addition, in their eagerness to win contracts, some households have rashly offered unrealistically high contract fees. When households have failed to meet contract targets, collectives usually have terminated the contracts or refused to carry out their own obligations. Collectives have rarely turned to the courts for redress owing to the difficulty of collecting a judgment against a peasant and the availability of administrative "self-help" measures. 
Poor contract drafting has contributed to its share of disputes. Most specialized contracts are drafted by village or team cadres unaccustomed to expressing detailed agreements in writing. Oral understandings are not always reduced to writing. For example, a contract may fail to stipulate that the collective will supply water each season to the contracting party even though the parties had so agreed during discussions leading up to the signing of the contract. Or contract terms are ambiguous-in one case discussed by a court, a rabbit breeding contract called for the contracting party to return to the collective a certain number of rabbits, yet failed to specify the rabbits' gender, size, or age. Yet another major problem has been that many contracts lack any provision covering damages or remedies in the event one party does not perform its obligations.

Proper management of valuable and fragile collective resources like fruit trees has also been an issue of contention. Collective leaders have unilaterally terminated contracts when they believe the peasant is irresponsibly managing the resource. If, however, resources are damaged by a natural cause beyond the control of the peasant, or if a natural calamity renders fulfillment of a contract impossible, collectives are usually willing to release the peasant from performance, reduce the contract fee, or extend the contract period. Disputes under these circumstances are rare.

Most fundamentally, disputes must be attributed to parties' failure to regard contracts as binding agreements. In the view of Chinese legal authorities, one of the prime causes of disputes is a "weak sense of law" (falü gainian danbo) among both peasants and cadres which leads to the routine breaking of contracts whenever a party finds it convenient to do so. In particular, many rural cadres, accustomed to the considerable personal power they have wielded, have not felt bound by contracts. Press reports about cadres terminating or modifying contracts at will or seizing property of a household as punishment for a contract dispute confirm that many cadres continue to believe their word is the law. ${ }^{17}$

\section{Policy and Laws Relevant to Rural Responsibility Contracts}

Laws and administrative regulations have not been instrumental to the responsibility system reform. Unlike companion economic reforms introduced in the Deng era, which have been implemented through numerous laws and regulations, the responsibility system reform has been implemented virtually entirely through Party policy. ${ }^{18}$ During the period from 1978

17. One of the more detailed of the many accounts of local cadres unilaterally terminating contracts can be found in the Jilin Daily, Mar. 2, 1985, at 1, translated in JPRS, CPS-85-058, June 14, 1985.

18. Although the importance of policy in Chinese political and economic life is universally acknowledged, many commentators do not distinguish between state policy and Party policy. The two are technically not the same: State policy is the policy of the government, usually given form in administrative documents of agencies or other governmental bodies, while Party policy is the policy of the Communist Party of China, which is announced in Party documents that may be publicly disseminated or circulated only in restricted circles. But the lines between the two types of policy can become blurred as Party policies are picked up by state organs and reflected in state policies. 
through 1984, as household responsibility farming of both collective grain land and specialized resources replaced collective management throughout the country, only one national law bearing on the responsibility system-the 1978 Provisional Work Regulations of the Rural People's Communesappeared. ${ }^{19}$ Party policy, announced through a series of publicly released and widely disseminated Central Committee documents, has driven and controlled the reform.

The responsibility system was officially introduced in 1979 by the "Decision of the Central Committee of the Communist Party of China on Some Questions Concerning the Acceleration of Agricultural Development."20 On the basis of this policy statement, production teams throughout the country began experimenting with labor contract systems under which they assigned production quotas to work groups while retaining centralized management control over production and distribution of income. During the next three years, from 1980 to 1982 , three major policy statements of the Central Committee and rural policymakers paved the way for peasant households to assume increasing control over production. ${ }^{21}$ By 1982, full

Furthermore, courts do not appear to distinguish between the two types of policy: Courts sometimes cite "state policy" (guojia zhengce) even though it is evident they have Party policies regarding the responsibility system in mind.

19. The Provisional Work Regulations of Rural People's Communes ("Commune Regulations") were passed on a trial basis by the Third Plenum in 1978 and are reproduced in Collection of Economic Laws and Regulations of the People's Republic of China 149 (1980). The Commune Regulations introduced the basic conditions for responsibility systems. The Commune Regulations stipulated that the basic accounting units of communes (usually production teams) enjoyed the right to carry out planting based on local conditions, to determine operation and management means, to allocate their own products, and to resist any "blind direction" by leadership organs. Furthermore, they mandated that communes base work compensation on the amount of work done rather than adhere to equal distribution.

20. Decision of the Central Committee of the Communist Party of China, reproduced in Collection of Agricultural Policies, Laws, and Regulations of the People's Republic of China: 1979, at 1.23 (1983). The Decision was approved in principle at the Third Plenum of the CPCCC in 1978 and circulated for comment and trial implementation. It was formally promulgated and implemented by the Fourth Plenum on September 28, 1979.

21. The 1980 Central Committee "Notice Printing and Issuing: [A Summary of] Several Problems in the Strengthening and Perfecting of the Agricultural Production Responsibility System" ("1980 Notice") sanctioned output responsibility contracting-a form of limited responsibility contracting in which compensation was directly linked to achievement of production targets-for specialized resources but discouraged such responsibility contracting for grain land except in remote and backwards areas. The 1980 Notice is published in Collection of Agricultural Policies, Laws, and Regulations of the People's Republic of China: 1980, at 4-1I (1983).

Specialized contracting was further encouraged by the March 1981 combined Central Committee and State Council "Notice Transmitting the State Agricultural Committee's 'Report on Actively Developing Multiple Types of Management in the Countryside" " ("1981 Notice"), which called on production teams to pursue specialized contracting through the organization of various forms of specialty teams, groups, households, and labor. Teams were also instructed to use contracts to encourage individuals or partnerships to run service, handicraft, animal raising, and goods transportation and sale operations. The 1981 Notice is published in Collection of Agricultural. Policies, Laws, and Regulations of the PRC: 1981, at 4-8 (1983).

The 1982 "Summary of the National Rural Work Conference" ("1982 Summary") reiterates Party backing of full responsibility contracting but also reveals resistance by some rural cadres to the reform. The 1982 Summary rebutted critics' charges that the system was a return to private farming and stressed the role of the collective in unifying management and use of land, constructing water works, accepting state planning guidance, and collecting collective dues. At the same time, though, it 
responsibility contracting of both specialized resources and crop land was widespread, although opposition to full responsibility contracting still existed in the Party ranks.

Any lingering doubts about the Party's commitment to full responsibility contracting were put to rest, however, by two key Party statements, the now famous Number 1 Documents of 1983 and 1984. The 1983 Number 1 Document took the final step of unconditionally endorsing full responsibility contracting, stating that "all places where the masses request the implementation of this system [of contracting out to the household] should actively support [the system].,"22 The 1984 Number 1 Document, ${ }^{23}$ the last Central Committee policy statement to focus on responsibility system reform, ${ }^{24}$ stressed stabilization of contract arrangements by providing that the contract period of land contracts should be lengthened to fifteen or more years; contracts for land development or reclamation were to be even longer. Two other important policy thrusts that have played important roles in adjudication of responsibility contract disputes were contained in the 1984 Number 1 Document: First, the Document provided that if peasants requested adjustment of contracts, collectives should make unified decisions on adjustments according to the principle of "overall stability and minor adjustments";25 second, the Document called for the "active support" of specialized households, which it described as having "taken the lead in making themselves rich through hard work, developing commodity production, and improving production techniques."

National laws and regulations ${ }^{26}$ governing some aspects of rural contracts were not promulgated until after the responsibility system and responsibility contracts had become firmly established in the countryside. Legislation directly governing some aspect of rural responsibility contracting is currently

stated that full responsibility systems were usually only suitable for products that could be managed in a decentralized manner; furthermore, brigades whose sideline production generated relatively large income were instructed not to use full responsibility contracting. The 1982 Summary is reprinted in Renmin ribao (People's Daily), April 6, 1982, at 1 \& 2.

22. The 1983 Number 1 Document is reprinted in People's Daily, April 10, 1983, at $1 \& 2$.

23. The 1984 Number 1 Document is reprinted in People's Daily, June 12, 1984, at 1 \& 2 . An English translation is available in 101 CHINA Q. 132-142 (1985).

24. The Number 1 Document of 1985 did not focus on the responsibility system, but, marking a second stage in rural reform, it announced the abolishment of the state mandatory procurement quotas and the introduction of the contract procurement system It also addressed in greater detail than previous policy statements the problems of developing marketing channels for farmers. It is reproduced in RuRal Laws and Regulations of China (1984), at 1-10 (1986).

25. 1984 Number 1 Document, at section 3, subsection 1. The purpose of adjustment through re-assignment was to reduce extreme fragmentation of plots, to take into account changes in a household's population due to births, deaths, or marriages, and to correct any unfairness in land assignments that had mistakenly occurred in the early experimental years of the reform.

26. Some regional regulations were promulgated to supplement policy directives. For instance, in 1984, the Fujian Provincial Government passed "Regulations on Agricultural Contracting Periods" which specify contracting periods and allow parties to assign contracts for several different types of natural resources. Another set of 1984 provincial regulations is the Jiangxi Provincial Government's "Regulations on Conscientiously Protecting the Legal Rights and Interests of Rural Specialized Households and Supporting Rural Specialized Households' Development of Commodities Production." Both sets of regulations are published in Chinese Rural LAwS AND Regulations (1984)-the Fujian Regulations at 82-84 and the Jiangxi Regulations at 84-89. 
limited to certain provisions of the General Principles of Civil Law, ${ }^{27}$ of various land laws, and of the Inheritance Law. ${ }^{28}$ Specific regulations on the responsibility system or responsibility contracts, long planned, have yet to be promulgated. ${ }^{29}$ The majority of the provisions do not break new ground, but serve instead to consolidate the responsibility system reform by statutorily legitimizing the contracting out of collective- and state-owned resources.

The provisions of the General Principles concerning responsibility contracting illustrate this statutory legitimization well. Articles 27 and 28 establish that the contract management household is a civil subject whose rights and interests are protected by law. ${ }^{30}$ In this respect, the Principles affirms existing legal practice: Since courts began accepting responsibility contract disputes in 1982, they have treated the contract household management household as an independent civil subject entitled to legal rights and independently liable for its legal obligations. Similarly, articles 80 and 81 grant legal protection to the right of citizens and collectives to manage under contract state- and collective-owned land and natural resources. ${ }^{31}$

27. The General Principles of Civil Law of the People's Republic of China ("the General Principles") are published in an English translation by Gray \& Zheng, 34 AM. J. CoMP. L. 715 (1986), and LAw \& Contemp. Probs., Spring 1989, at 27. All citations of the General Principles' provisions are based on Gray \& Zheng.

28. The Inheritance Law of the People's Republic of China was adopted at the Third Session of the Sixth National People's Congress on April 19, 1985, and took effect on October 1, 1985 (the "Inheritance Law"). To encourage individuals to undertake responsibility contracting, article 4 of the 1985 Inheritance Law provides: "An individual's earnings from an individual responsibility contract should be inherited in accordance with this law." Thus, in the event a contracting party dies during the contracting period, her heirs are entitled to the income from the contract. In the same spirit of promoting contracting, especially of resources that require long-term investment, article 4 adds that where the law allows an heir to continue a responsibility contract, she may do so as provided by the contract.

One problem raised by this provision is that many contracts do not contain a clause on assignment upon death of the contracting party. But it appears that if local regulations do not prohibit an heir from continuing a contract, and collective leaders feel the heir possesses adequate production management skills or experience, she will be able to assume the contract. See Legal Advice Column, Zhongguo fazhibao (China Legal News), May 19, 1986, at 3; and 3 Renmin SIFA (People's Judicature) 27-28 (1986).

29. Work on the drafting of regulations on responsibility contracts has been underway since 1984 at the Department of Agriculture, Animal Husbandry, and Fisheries; but promulgation of the regulations has been delayed by both theoretical and practical obstacles. One theoretical dispute has been, for example, over the relationship of responsibility contracts to economic contracts; this controversy bears on the extent to which the regulations will draw on the Economic Contract Law. Practical problems impeding promulgation of regulations have included the still unsettled nature and function of rural political organizations like the villagers' committees that are involved in the responsibility contracting process.

30. Article 27 defines contract households as "members of rural collective economic organizations who, in accordance with provisions of a contract, conduct business with respect to goods within the scope permitted by law. . . " The "contract" household thus differs from the "natural" household: It is created by a contractual agreement and includes only those members of a natural household who actually participate in the business. The definition is a broad one that sweeps in not only households with specialized contracts but also households with "ordinary" land contracts; earlier versions of the General Principles had granted legal status only to households contracting for specialized production. Article 28 states that "the lawful rights and interests of individual industrial/commercial households and rural contract-operation households are protected by law."

31. Article 80 states: "The right of a citizen or collective to operate according to law under contract either land owned by a collective or state-owned land that is used by a collective is protected by law. The rights and duties of both contracting parties are determined by the contract in 
In Chinese legal theory, this "contract management right" (chengbao jingyingquan) consists of three sub-rights: the right of occupation (zhanyou quan), the right of utilization (shiyong quan), and the right to benefits (shouyi quan). ${ }^{32}$ The contract household therefore enjoys legally protected rights to occupy the contracted land or natural resources, rights to use the contracted property in the manner stipulated by the responsibility contract, and rights to claim the benefits flowing from the contracted property in the manner prescribed by the contract. In fact, courts had been protecting contract households from unauthorized intrusions on their contracted land and protecting their profits from contracts prior to the appearance of the Genieral Principles. From the perspective of legal theory, articles 27, 28, 80, and 81 are significant, for they lay the legal foundation for China's newest form of agricultural production management. From the perspective of legal practice, they seem destined to have little impact. ${ }^{33}$

accordance with the law." Article 81 states: "The right of citizens or collectives to operate according to law under contract the forests and woods, mountain land, grassland, undeveloped land, shorelines, and bodies of water that are owned by a collective or owned by the state and used by a collective is protected by law. The rights and duties of both contracting parties are determined by the contract in accordance with law."

32. See Ye, The Contract Management Right 31 -33 (1987).

33. The sole new legal rule directly governing responsibility contracts introduced by the General Principles addresses the issue of how obligations of contract households are to be satisfied. Article 29 of the General Principles states: "Obligations of individual industrial/commercial households and rural contract-operation households are borne by individual property if the business is operated by individuals, or, if the business is operated by a family, the property of the [members of the] family." No established judicial practice concerning the property to be used in satisfying contract household liabilities appears to have existed. The real-world utility of article 29 , however, is uncertain, for no method of distinguishing individual property from family property, practical or legal, presently exists under Chinese law.

Provisions of land laws concerning responsibility contracting function in the same way as the General Principles, i.e., they legally fix rural policies rather than establishing new norms. Article 22 of the Law on Forests of the People's Republic of China ("the Law on Forests") states that state- and collective-owned barren hillsides and land suitable for afforestation "may be contracted out to collectives or individuals for afforestation." Article 4 of the Law on Grasslands of the People's Republic of China ("the Law on Grasslands") states that state- and collective-owned land (as well as state-owned land that is under stable, long-term collective use) "may be contracted out to collectives or individuals to engage in animal husbandry production;" and article 12 of the (1986) Law on Land Management of the People's Republic of China ("the Law on Land Management") provides that state- or collective-owned land may be contracted out for the purposes of agriculture, forestry, animal husbandry, or fishery production. Responsibility contracting for all of these purposes, however, had been practiced for several years prior to the laws' enactment and had been officially sanctioned in the 1983 Number 1 Document. The official text of the Law on Forests is published in the Guowuyuan gongbao ("Bulletin of the State Council") No. 444 (October 10, 1984), at 771; the official text of the Law on Grasslands in id., No. 470 (July 10, 1985), at 579; and the official text of the (1986) Law on Land Management in id., No. 505 (July 10, 1986), at 531. (The Law on Land Management was revised in 1989 and appears in revised form in the Bulletin of the State Council, No. 580 (January 10, 1989), at 873.)

Similarly, the General Principles and the land laws give statutory form to well-established and frequently reiterated policies on the proper use of state and collective property that is contracted out. Articles 80 and 81 of the General Principles provide that land, mineral resources, waters, and natural resources belonging to the state or collectives "may not be bought and sold, leased, mortgaged, or by any other means illegally transferred." The Law on Land Management, article 12, stipulates that collectives or individuals who contract to manage land have the duty, in accordance with the contract provisions, to "reasonably use" the land. 
While the responsibility system reform itself has proceeded essentially in a non-legal environment, law has played a role in the court resolution of responsibility contract disputes. As discussed below, after some initial disagreement about its applicability to rural responsibility contract conflicts, the Economic Contract Law of the People's Republic of China ("the Economic Contract Law"), which took effect in July 1982,34 has clearly emerged as a major decisional guide.

\section{The Courts' Recognition of Responsibility Contracts as Legally Enforceable Agreements}

Although some responsibility contract disputes reached courts as early as 1980 and 1981, most courts did not begin hearing the disputes until 1982 or $1983 .{ }^{35}$ Even then, courts initially hesitated as they wrestled with the issue of whether the contracts were legal agreements to be enforced by the courts or administrative, "internal" (neibu) agreements between a unit and one of its subordinates to be regulated by administrative organs under labor law principles.

The novelty of the contracts and the lack of any law governing them made this question more difficult to answer. On the one hand, judges acknowledged that in the formation of the contracts parties enjoyed equal status and that the contracts created legal rights and duties which should be enforceable in court. On the other hand, judges believed that since the contracts were formed between collectives and their members and did not involve any commodity exchange, they represented an administrative, superior/subordinate relationship; ${ }^{36}$ for this reason, they were more akin to labor contracts than to economic contracts. Some judges even questioned whether they were not contracts so much as an administrative means of management. In addition, some felt that responsibility contracts could not be considered economic contracts because only one party to the contract (the collective) was a legal person; the Economic Contract Law defined economic contracts as agreements between legal persons for the achievement of an economic purpose. In rebuttal to this position, others pointed to article 54 of the Economic Contract Law, which states that economic contracts between

34. The official text of the Economic Contract Law is published in the Bulletin of the State Council, No. 373 (January 25, 1982), at 864. The Law was adopted by the Fourth Session of the Fifth National People's Congress, Dec. 13, 1981, and took effect on July 1, 1982.

35. Judges of the Supreme People's Court stated that courts throughout the country started hearing the cases in 1982; one of the courts interviewed by the author stated it did not try the cases until 1983. However, the author has seen unofficial reports of cases tried in 1980 and 1981.

36. This analysis would seem to lose force, however, with the appearance of responsibility contracts between collectives and peasants from outside the collective; in such cases it was difficult to assert that any administrative relationship derived from the parties' status existed, unless one took the position that administrative relationships could be "stepped into" by the signing of a responsibility contract. 
rural commune members and legal persons should be carried out in reference to it. ${ }^{37}$

Not all of the courts' doubts about accepting responsibility contract disputes should be attributed to the legal vacuum into which the contracts arrived. For at least some courts, pragmatic considerations were also a factor. Courts feared that their limited resources would be overwhelmed by large numbers of the disputes, and perceived that the disputes would be difficult to resolve because they were relatively complicated, had policy ramifications, needed to be handled in a timely fashion, and required taking popular opinion into account. ${ }^{38}$

Despite these doubts, many courts started to accept the disputes in 1982. It is not known whether the Supreme People's Court issued informal guidelines at around this time; in some areas, the decision to try responsibility contract cases appears to have been made by the provincial higher level courts. For example, in late 1982, the Henan Province Higher People's Court, responding to an increasing number of queries from lower level courts, decided that designated basic level and intermediate level courts in the province were to accept the disputes on an experimental basis; it was not until 1984 that all courts in the province were opened to the disputes. ${ }^{39}$ Courts in the Beijing, Shijiazhuang, and Chongqing metropolitan areas also began taking disputes on an experimental basis in 1982.40 Official confirmation of this practice did not come until March 1984, when the First National Economic Trial Work Conference organized by the Supreme People's Court decided that rural responsibility contract disputes fell within the scope of cases accepted by the economic divisions of courts. ${ }^{41}$ By this time, though, many courts around the country had been handling the disputes for some time.

\section{E. The Importance of Dispute Resolution by Administrative Offices}

Notwithstanding the decision of the courts to try responsibility contract disputes, resolution of the disputes-whether a mediated settlement or a judgment-through the offices of a court remains the exception rather than

37. For a summary of the debate over the nature of responsibility contracts and whether courts should accept responsibility contract disputes, see, e.g., 2 Faxue (Jurisprudence) 27-30 (1985). Though on its face article 54 does appear to cover responsibility contracts, at least those concluded between a collective and a household belonging to the collective, it was probably drafted with sales contracts between collectives and peasants, not responsibility contracts, in mind. In 1980-81, at the time the Economic Contract Law was being drafted, responsibility contracts were relatively new and Party policy on responsibility contracting was still evolving.

38. See Report of Fenghua County People's Court, Jiangsu Province, in 3 Jingjı fagui YanjIU ziliao (Research Materials on Economic Laws and Regulations) 24 (1985) [hereinafter RESEARCH Materials].

39. Interview with Henan Province Higher People's Court officials, November 11, 1986.

40. Interviews with officials of the Beijing Higher People's Court, April 4, 1986, and with a judge of the Zhengding County basic level court, October 22, 1986; see also Liu, Contract Disputes, in 3 Weiding gao (Draft Papers) 23 (1985).

41. See "Notice on Strengthening Economic Trial Work," issued by the Supreme People's Court and summarized in China Legal News, December 11, 1985, at 2. 
the rule. When disputes flare up, few aggrieved parties immediately consider pressing their rights through legal action. If the aggrieved party is a peasant household, it will normally appeal for help to local government or Party officials (who are often one and the same in rural areas) such as local Party secretaries, township government cadres, and members of the county Party Committee. It is usually only when no help is forthcoming from these traditional centers of rural authority that a peasant may finally turn to the courts; whether he decides to sue or not depends on his awareness of his legal rights, his willingness to endanger relations with collective leaders, and his perceptions of the local court. If the dissatisfied party is a collective, it will often use its considerable administrative powers to rectify the perceived wrong; for instance, it may freeze the account of the enterprise managed by the peasant or refuse to supply the peasant with production inputs such as water, electricity, or fertilizer.

Even if parties decide to bring suit, courts will often turn cases over to administrative departments-usually the township government (if it is not a party to the dispute) or the district government-for resolution. ${ }^{42}$ Since resolution by administrative organs usually consists of mediation-on occasion, if parties are unable to reach an agreement, the administrative organ may render a decision that is non-binding on the participants-court preference for administrative resolution of disputes may be interpreted as a manifestation of traditional Chinese preference for non-confrontational conflict resolution.

In the case of rural responsibility contracts, however, the courts' preference for administrative handling of disputes also is based on their belief that local governments are best equipped to handle the disputes. This belief rests on several grounds: First, courts reason that since the handling of this type of conflict may have wide-ranging repercussions, the authority and regional perspective of a local government is needed; second, courts feel that local governments will be more familiar with the disputants and local circumstances; and third, courts believe that the administrative relationship between a local government and disputants will simplify investigation of the case's facts and enforcement of a resolution. ${ }^{43}$

Courts interviewed by the author uniformly stressed that resolution through administrative channels continues to be strongly encouraged but is not mandatory; a party retains the right to sue in court if it wishes. Furthermore, because of the national policy of strongly protecting the rights of specialized households, ${ }^{44}$ courts may be relatively willing to hear controversies involving specialized households. ${ }^{45}$ At the same time, it also appears that some courts have had a policy of not accepting a dispute until

42. Courts usually will do this by refusing to accept the dispute; in some instances, however, courts may initially accept a dispute but subsequently ask the local government to take the lead in resolving the dispute.

43. See Report of Fenghua County Court, 3 Research Materials, supra note 38, at 24 \& 27.

44. See text accompanying note 10 supra.

45. See Report of Fenghua County Court, supra note 43, at 28. 
adminstrative organs have first tried to resolve it; ${ }^{46}$ and in some cases where court proceedings are already underway, courts may "persuade" parties to accept administrative efforts at settlement by notifying the parties that it will halt court proceedings until administrative means have been tried. In the case involving an orange grove contract described in detail below, ${ }^{47}$ the court informed the plaintiff's lawyers that it would suspend its involvement in the dispute and let the township government attempt to resolve it; if its efforts failed, then the court would proceed to render a judgment. When informed of the court's decision, the plaintiff expressed misgivings about having the township government intervene but eventually agreed to this course of action at the urging of his lawyer, who reassured him that he could refuse to accept the government's proposed resolution. Had the plaintiff insisted that the court continue its proceedings, the court probably would have relented, but with prejudice to the plaintiff.

\section{Norms and Other factors That Have Guided Courts in the Adjudication of Rural Responsibility Contract \\ DISPUTES}

Analysis of the rules and other decisional bases that guide Chinese courts in their adjudication of economic disputes, including responsibility contract conflicts, must be conducted cautiously. Two problems complicate the inquiry: the continuing role of the Party in dictating court decisions and the limited nature of currently available materials on the judicial process.

Party domination of judicial affairs has characterized political-judicial relations since the founding of the PRC. Judicial independence, established in principle by the 1954 Constitution during the mid-1950's movement to develop socialist legality in China, has never existed in practice. Even during that short-lived period of legal institution-building, the Party, if it did not directly intervene in court decisionmaking, exerted control over the judiciary through control over judicial personnel.48 Party monitoring of and control over the judicial process today continues through the political-legal committees that have been established at various level to review judicial work. This lack of judicial autonomy suggests that a quest to find the standards or rules that guide judicial decisionmaking is simply superfluous, or worse, potentially misleading: If the Party determines all judicial outcomes (or nearly all), then court reference to laws, administrative regulations, policy, or other decisional guides is largely an exercise in form.

But there is reason to believe that the Party today no longer systematically intervenes in all, or the great majority of, civil lawsuits. Since the epochal

46. See Shui, An Opinion on the Handling of Agricultural Production System Contract Disputes, 3 FAXUE zazhi (Jurisprudence Magazine) 57 (1984)

47. See text accompanying note 92 .

48. See Baum, Modernization and Legal Reform in Post-Mao China: The Re-birth of Socialist Legality. XIX Studies in Comparative Communism 69, 78 (1986). See also id. at 79-80, 83, and 91-92. 
Third Plenum of the Eleventh Central Committee in 1978, which called for construction of a strong legal system, Party intervention in ordinary judicial matters has been openly criticized ${ }^{49}$ and the government has implemented measures, including the training of professional judges, to strengthen the judicial system. From a practical perspective, the sheer volume of cases accepted by the courts in recent years seems to preclude the possibility of Party review of all disputes. On the basis of these developments, it seems justifiable to posit that Party intervention in court decisionmaking has decreased to some degree, ${ }^{50}$ thus leaving Chinese judges with some, if closely circumscribed, autonomy to determine how a case should be handled and some latitude to look to different sources of rules or authority for guidance. ${ }^{51}$ The following analysis is based on this assumption. In the author's opinion, a study of decisional factors can contribute to an understanding of the civil adjudication process in China; however, the search for norms or other factors that guide judges must be anchored in the acknowledgment that they may frequently or occasionally be secondary or irrelevant in a judicial system that is still very closely controlled by members of the ruling political elite.

Research constraints also significantly limit the depth of any study on the process by which Chinese courts reach their decisions. Access to primary judicial materials and judicial personnel is extremely limited. The Chinese judicial system remains essentially a closed institution, largely impenetrable not only to foreigners but also to most Chinese. With the exception of occasional cases deemed to be of general instructional value that are published in the Bulletin of the Supreme People's Court, copies of court decisions

49. See id. at 91-92, citing media articles and statements of legal officials calling for greater judicial independence. For a prominent jurist's statement that there should be less Party involvement in judicial work, see Chen, Thirly Years of Legal Studies, translated in 2J. CHIN. L. 181, 195 (1988).

50. On the other hand, Party involvement is certain in cases that are politically sensitive, raise novel questions of law or policy, or center on large sums of money or large enterprises. In such cases, courts will routinely consult with local Party officials as well as with the superior court. Furthermore, local Party leaders may sometimes use their power to block court action. For example, in one case reported from Jilin Province, despite donations by the contracting household to his collective to quell leaders' and villagers' grumblings over his profitable orchards, the production brigade seized the orchards and re-contracted them out to three groups. When the peasant sued the brigade, county and district Party committee leaders repeatedly intervened, even over contrary instructions from higher authorities, to block adjudication of the case by the county court. The county Party committee then made its own determination that the contract was invalid and unilaterally rescinded it. Although the subsequent course of developments is not entirely clear, this incident apparently was brought to the attention of higher Party authorities, who ordered the county committee to restore the contract and to allow the county court to try the case. Interestingly, no account of the case's outcome is given. See U.S. Joint Publication Research Service 77-82 (June $14,1985)$.

51. Diminished Party intervention in judicial decisionmaking does not imply that individual judges or individual courts reach decisions completely on their own. On the contrary, consultation among judges or different courts is the norm. Individual judges will almost always consult the head judge of the court-or the head judge will impose his opinion-before handing down a decision or taking a stance in a dispute. And if a dispute is large or complex enough, lower courts will ask for instructions (qingshi) on how to proceed from their superior court. But the fact that the judgment rendered, or settlement negotiated, by a court reflects the views of more senior members of a court or higher court instead of the judge presiding over the case should not affect an analysis of the factors that influence judicial decisionmaking in general. 
are not published, ${ }^{52}$ and even Chinese law specialists cannot count on access to them. Despite the Code of Civil Procedure's provision that trials, unless they involve state secrets or private matters, are to be publicly conducted, only a handful of pre-selected trials are conducted publicly. ${ }^{53}$ Judges do not publicly comment on decisions of their courts. Faced with this situation, the researcher is forced to rely on secondary sources-articles in legal journals, newspaper reports, and published collections of cases-which are usually simplified accounts that provide only a glimpse into the judicial process.

Even for those fortunate enough to be in possession of actual court opinions, knowledge of the reasoning process behind decisions remains elusive owing to the summary nature of most Chinese court opinions. Opinions do not contain the detailed and often complex legal reasoning that characterize opinions of common law courts. They typically consist of only a brief recital of the case's main facts, a few sentences summarizing the procedural history of the case (procedural issues are rarely discussed in any detail), a summary of the court's investigation, and a concluding paragraph or two stating the court's ruling. Legal bases for the decision may be cited in this last section. The court's rationale for applying a law or interpreting a law in a particular way is not given. While policies, laws, and administrative regulations are cited as bases for decisions, other factors that may have guided the court-for example, Supreme Court guidelines concerning handling of a certain type of dispute or equitable principles-are not explicitly mentioned, though a court's reliance on them may be inferred from the opinion.

Much of the analysis below is based on published reports of responsibility contract cases and is subject to the inherent limitations described above. Thus, to sunplement this material, the analysis also draws from two other types of sources: (1) interviews conducted by the author with the basic level court of Zhengding County near Shijiazhuang, the basic level court of Yixing County near Wuxi, the intermediate court of Beijing, the higher court of Henan Province, and the Supreme People's Court;54 and (2) a small number of materials that have not been publicly circulated.

52. Even were the judicial system to evolve into a more transparent one-recently there have been calls for greater judicial openness-materials for analyzing the judicial process will remain scanty as long as Chinese legal authorities rigidly adhere to the reasoning that since courts do not make law, there is no need to publish decisions other than the occasional one of special significance. While this attitude would seem to ignore the goal of consistency in decisionmaking, it is possible that Chinese authorities believe that consistency can be achieved through internal dissemination of guiding cases, internal distribution of Supreme Court guidelines, judicial work conferences, and other non-public means of informing judges about proper interpretation of laws. Obviously, these internal directives or guidelines will not aid disputants or lawyers.

53. Article 103 of the Code of Civil Procedure of the People's Republic of China ("Code of Civil Procedure") stipulates that the trial of civil cases by the people's court shall be conducted openly, except for certain cases which involve state secrets or personal private matters, or cases which the law stipulates shall not be conducted openly.

54. China's judicial system consists of four levels of courts: basic level (jiceng) courts, which are the courts of first instance for smaller disputes; intermediate (zhongii) courts, which review the decisions of basic level courts and also serve as the courts of first instance in disputes involving foreign parties and in larger, more complex, and more sensitive disputes; higher (gaoji) courts, which review decisions of inferior courts and act as the courts of first instance for cases that are of 
Chinese courts appear to be guided in their handling of responsibility contract disputes by a number of different sources of authority, some legal in nature, some not. These decisional guides fall into four categories: Party policies; legal norms, among which the most important is the Economic Contract Law; the basic principle of fairness in contractual relations and commercial dealings; and the opinions of local government or administrative offices.

\section{A. Party Policies}

The courts' handling of responsibility contract disputes has been guided first and foremost by Party policies on rural responsibility contracting. Judicial attention to Party policies on responsibility contracting is indicated by citation to policy in case reports, frequent references in court-authored commentaries on contract disputes to policy as a guide, ${ }^{55}$ and the comments of courts interviewed by the author. ${ }^{56}$ Close identification of rural responsibility contracts with national Party policies and the absence of any laws or regulations specifically governing the contracts has led to an unusually critical role for policy in court decisionmaking.

The judiciary's protection of the rights of contract households through enforcement of responsibility contracts which collectives attempt unilaterally to terminate or modify, frequently reported in the press during 1984 and 1985, has been a policy-driven response. Two of the major themes stressed by Party policy during 1982-85, the period from which most of the cases described in this article are drawn, were: (1) "stabilization" of responsibility contract arrangements, that is, clarification of rights and duties under existing contracts and the avoidance of major shifts in contract arrangements; and (2) the protection of the lawful interests of specialized households. Party leaders in charge of agriculture believed these policies were essential for increasing productivity, encouraging investment in land and other agricultural resources, and furthering specialization-the development forces which were to transform a subsistence economy to a commodity economy and lift the Chinese peasantry from poverty. A clear corollary of these policies was the legal protection of responsibility contracts and the rights of contract households against the arbitrary actions of rural cadres. These policy

significant import in the region under its jurisdiction; and the Supreme People's Court, the highest appellate court and the court of first instance for cases that are of national significance and other cases that it determines should be tried by it. There are no set monetary limits that determine jurisdiction over disputes. Most rural responsibility contract disputes involve relatively small amounts of money-less than 10,000 yuan (approximately 2700 U.S. dollars) and often only a few thousand yuan-and are thus tried by basic level, county courts.

55. See, e.g., the report of the Jinzhou Intermediate Court of Liaoning Province, A Concise Discussion of the Handling of Rural Production-Linked Responsibility Contract Disputes: The Issue of Applicable Law, in 3 Research Materials, supra note 38 , at 12. In addition to stating that policy can be a basis for deciding disputes when there is no applicable law, the court remarks that responsibility contract disputes carry strong policy ramifications.

56. The Beijing Intermediate Court, for example, stated that the handling of responsibility contract cases was largely determined by policy. Other courts stated that policy was an important guide, particularly the Number 1 Documents of 1983 and 1984. 
priorities $^{57}$ were not lost on the courts which began to render decisions in favor of households in cases where collective leaders, resentful of peasants' profitable operations, unilaterally terminated or modified contracts or physically interfered so as to make performance of the contract impossible. ${ }^{58}$ Not only were these decisions publicized in mass media to demonstrate to Chinese citizens that responsibility contracts would receive legal protection; they were also documented in local Party and judicial documents for the edification of Party and judicial cadres. ${ }^{59}$

The primacy of Party policy in the judicial decisionmaking process is also demonstrated by cases in which courts have supported the termination or modification of contracts by collective leaders because the leaders were responding to new policy priorities. Indeed, one judge of the Supreme People's Court who has specialized in the handling of responsibility contract disputes has written that when policies or laws change, courts may need to terminate or modify contracts. ${ }^{60}$ Thus, in certain cases, courts have ruled against peasants demanding continuation of a contract even though the collective appears to be breaching the contract in violation of Economic Contract Law rules.

One illustration of this is a 1983 dispute from Fenghua County in Zhejiang Province. The dispute arose when, during implementation of the reform policy of dismantling communes and establishing separate township governments and cooperative economic organizations in their stead, ${ }^{61}$ the management committee of the brigade in Fenghua was changed to a villagers' committee (cunmin weiyuanhui) and ownership of tea-growing land originally owned and managed by the brigade transferred to six separate villagers' groups (cunmin $z u$ ) under the new villagers' committee. To consummate the structural re-organization, the villagers' committee then unilaterally terminated a responsibility contract for the tea-growing land which its predecessor, the management committee, had signed with fourteen

57. It seems quite possible that Party directives on the protection of contracts were sent directly to courts, either through the Supreme Court or through local Party committees.

58. See, e.g., China Daily, June 9, 1983 (court ruling orchard contract of eight peasants protected from unilateral revocation by cadres in Henan); report of Yueyin District Intermediate Court, 5 Fazhi yuekan (Legal System Monthly) $12-13$ (1985); Fujian ribao (Fujian Daily), April 1, 1983; report of Hubei Province Higher Court, 1 Faxue pinglun (Legal Studies Commentary) 35-39 (1985); and three cases reported by Zweig et al., supra note 16, at 340-46, 351-52, in which courts, ruling in favor of households suing the collective representatives, upheld specialized contracts.

59. For example, one document read by the author, a report circulated by an intermediate court on a specialized contract in which the contract household prevailed, was entitled "Utilize Legal Weapons" and "Protect the Legal Rights and Interests of Specialized Contract Households."

60. See Shen, How to Handle Rural and Urban Responsibility Contract Disputes 25 (1987).

61. Beginning in 1982, in order to separate governmental and economic functions that up to then had been combined in the commune, communes across the country were dismantled. Governmental functions were vested in newly created township people's governments (at the level of former communes) and villagers' committees (at the level of former brigades) were established as grass-roots, self-governance units. In a number of areas, however, villagers' committees actually functioned as local arms of the township government. The economic functions of communes were vested in newly established cooperative economic organizations at various levels; the names and levels of the organizations vary from locality to locality. 
households. It also demanded that the households add an extra 3800 yuan payment to the past year's contract fee. The court, citing the Economic Contract Law, decided that the villagers' committee must assume responsibility for the breach of the contract ${ }^{62}$ and ordered it to return the 3800 yuan. However, citing the "spirit" of the 1983 Number 1 Documentwhich had specifically called for commune restructuring63 -other Central Committee Party "policy regulations" (zhengce guiding) concerning the restructuring that it did not specifically name, and the demands of the "actual situation," which necessitated transferring ownership and management rights from the brigade (villagers' committee ) level down to the village group level, the court also ruled that the contract could not be continued. The court reporting this case cited it as an example of how to handle the relationship between the Economic Contract Law and current policies. ${ }^{64}$

General land contracts have been even more susceptible to evolving policy. The 1984 Number 1 Document, which stipulated that the period for land contracts was to be extended to fifteen years or more, also added that prior to the extension of contracts, "if the masses requested adjustment of land (allocations and contracts)," the collective could adjust contracts following the principle of "overall stability and minor adjustments." In fact, adjustment of contracts was usually initiated by collective leaders with acquiescence by households. In one reported case where a peasant refused the collective's request that he give up part of the land he had contracted for because the size of his household had decreased, the court ruled that the contract was no longer valid and recognized a new contract for the land that the collective had signed with another party. It based this decision on its finding that the termination of the first contract accorded with the policy of "minor adjustments." 65

When a court uses policy to reach a decision, it may explicitly state that it has reached its conclusion on the basis of policy. Any reference to policy, however, is likely to be general. Thus, a court will usually simply state that the type of contract before it should be upheld and protected or note that a party's action was proper because the contract or action accords with "policy" or the spirit of policy. It will not cite specific provisions of a policy document. Where courts have cited specific policies, those policies have been the 1983 and 1984 Number 1 Documents. Moreover, due to the inherent generality of policy, the specific solution to a conflict that a court devises depends more on its own sense of what is fair, relevant local regulations, and local conditions-

62. The court's report did not state if the committee had to pay compensation for the breach.

63. See section 5 of the 1983 Number 1 Document.

64. The court's report of the case is published in 11 Research Materials, supra note 38 , at 28 29. Unfortunately, the report gives no explanation of why ownership rights had to be adjusted as part of the adjustment. Furthermore, it is not clear why, even with the ownership change, the villagers' committee could not continue the contract: It has been common for villagers' committees to act as the party contracting out land even where the land is technically owned by villagers' groups.

65. See 5 Legal System Monthly 13 (1985). 
including the opinions of local administrative or government leaders-than on policy.

These points are illustrated by a case from Xinjiang involving a dispute between a farm laborer who orally contracted to plant wheat on land he had reclaimed and his team leader, who subsequently denied there had been any agreement and ordered that the wheat be distributed equally among all members of the collective. Although the local bureau in charge of farms worked out a compromise arrangement, the laborer was forced to sue when the agreement was violated by members of the collective. The court declared that contracting to reclaim and plant barren land was permitted by state policy and should therefore be supported and protected, that the "oral agreement" was legal (although no specific law is cited), and that any responsibility for the contract's incompleteness lay with the leaders of the team. It then mediated a settlement under which the parties agreed to abide by the compromise arrangement and the defendant team leader agreed to pay the laborer the bonus stipulated by the contract for surplus production. ${ }^{66}$

In some cases, the courts do not explicitly acknowledge the role of policy but nonetheless appear to base their decisions on policy grounds. Courts will, for example, refuse to uphold contracts where there has been manipulation of the bidding process for the contract. An important principle of the responsibility contract system is that contracts, both land and specialized ones, are to be concluded through democratic processes; the 1982 "Summary of the National Work Conference" 67 states that "the signing of contracts shall be done through democratic consultation." 68 In other words, the awarding of contracts is to be free of nepotism or favoritism. On the basis of this policy, courts will find contracts void if there have been bidding irregularities. Thus, in one Henan Province case, the court refused to uphold the apple orchard contract of a party who had won the contract by submitting a bid, apparently approved by the team leader, which stated "ten yuan more than the highest bidder." 69

Similarly, courts will allow a collective to terminate a contract if they are convinced that the contracting party is guilty of exploitative management of the collective's resources. Another important principle of the responsibility system has been that the contracting party's right to use collective land and natural resources is conditional on its proper use and preservation. Judges of the Beijing Intermediate Court cited exploitative management as a violation of state policy. ${ }^{70}$ Thus, even if the contract itself does not state that the contracting party must refrain from unauthorized chopping of trees, premature picking of fruit, overmining, or other types of exploitative resource use, courts will terminate contracts if there is evidence of such exploitation.

66. See SHEN, supra note 60 , at 26-27.

67. See note 22 supra.

68. Section 6 of the 1982 Summary.

69. Nongmin ribao (Peasant's Daily), March 28, 1986, at 3.

70. Interview with officials of the court, April 8, 1986. 
Protection of the state and collective's economic interests is another policy that may lead courts to modify contracts. This policy is summarized in the phrase of "taking care of three [interests] at the same time" (san jian gu), or the principle that the responsibility system must consider concurrently the interests of the state, the collective, and the individual. ${ }^{71}$ Specifically, the state interest is the contract's production quota (where there is one) and rural development; the collective interest, the collective dues (for land contracts), or the contract fee (for specialized contracts), and protection of its resources; and the individual interest, his contract rights, including profits from management of the resource. Although they did not cite any specific cases, the Henan Province Higher Court and the Beijing Intermediate Court stated that they would be prepared to modify a contract where unanticipated price changes had created a windfall to the contracting party. However, both courts stressed that they would first attempt to persuade the contracting party to modify the contract terms voluntarily. ${ }^{72}$

Two very important final points concerning the role of policy in responsibility contract disputes remain to be made. First, policy's general nature makes it a very flexible tool in the hands of the courts. The existence of universally studied, major policy statements, such as the Number 1 Documents for the rural responsibility system, does not necessarily bring uniform results in courtrooms across the country. Even though courts will always consider policy when approaching a dispute, their interpretations of policy-how it applies to a given situation-can vary. Thus, in a case from Ningxia, a court faced with the interpretation and application of the 1983 Number 1 Document reached the opposite result from the one which the Feng Hua court reached. It concluded that the policy of perfecting the responsibility system called for in the Document did not require termination of a contract. The court rejected the defendant's argument that its unilateral termination of a contract had been correct because the 1983 Number 1 Document emphasized the need to improve the responsibility system. It supported instead the plaintiff's position that it was a distortion of Party policy and a violation of the Economic Contract Law to treat the termination or modification of a contract at will as an effort to perfect the responsibility system. The court ruled that the contract would be upheld and was to be performed under its original terms.

Admittedly, the circumstances of this case differed from those of the Fenghua case; it appears that the defendant's main motive for ending the contract was not to improve management of the orchards, a purpose that might have received the court's approval, but to deprive the plaintiff of large profits he was reaping under the contract. Had the defendant's motives been

71. See, e.g., section 7, point 6, of the 1983 Number 1 Document. See also the remarks of Du Runsheng, in Du, supra note 10, at 65 , on the issue of unifying the interest of the individual with the interests of the state and collective.

72. See text accompanying note 103 infra for another perspective on courts ${ }^{\circ}$ willingness to modify contracts in these circumstances. 
purer, the Ningxia court might have chosen to end the contract, as did the Feng Hua court. Nonetheless, the contrast between the two cases shows the great leeway courts have in applying policy to specific situations.

Second, courts generally will not base their decisions on policy when they can use the Economic Contract Law or administrative regulations to resolve the dispute and the results of applying the Economic Contract Law or regulations would not contravene policy. In other words, if a provision of the Economic Contract Law or a regulation addresses the issue at the root of a conflict, a court will apply it as long as it is convinced the result furthers policy. Thus, most reported decisions have rested on the Economic Contract Law rather than on policy, though there is reason to believe that legal rules are subordinate to policy goals and that policy considerations generally shape the approach of courts toward disputes.

Courts apply law whenever possible for both theoretical and practical reasons. Theoretically, the use of law is called for because law represents a "fixing" of policy, in a specific and relatively stable form, after the wisdom of that policy has been confirmed. ${ }^{73}$ Thus, where Chinese law contains a provision addressing the legal issue, the provision should be applied; policy need be consulted only where no applicable law exists. ${ }^{74}$ Additionally, law, an expression of state will, is mandatory in nature and courts are the state organs responsible for enforcement of state laws. In contrast, the implementation of policy is not a job for the courts: Theory holds that policy, the means through which the Party exercises its leadership of the state, is only directive and should be implemented primarily through persuasion, education, encouragement, and the example of Party members. ${ }^{75}$ Practically, courts use a law when appropriate because it is more specific than policy, providing a rule in comparison to a general principle. Courts may also favor law-based decisions under the reasoning that since peasants believe law is less likely to change than policy, a decision based on legal rules will do the most to convince peasants that their contracts will be protected.

\section{B. Legal Bases: The Economic Contract Law and Administrative Regulations}

1. The Economic Contract Law. In the absence of any laws or regulations specifically governing responsibility contracts, courts have relied on the Economic Contract Law as a source of legal standards to apply to disputes. Although the introduction of responsibility contracts sparked a debate in academic and judicial circles on the "nature" of the contracts and the question of whether the Economic Contract Law governed them, ${ }^{76}$ case

73. See, e.g., Chen \& Zhang, Basic Theory of Jurisprudence 234 (1981).

74. See, e.g., article 6 of the General Principles, which states: "Civil activities must be in conformity with the law; where there is no provision of the law, activities must conform with state policy."

75. CHEN \& ZHANG, supra note 73 , at 229.

76. The "nature" of responsibility contracts and the question of what substantive law governs the contracts has been much discussed by legal writers. Moreover, debate has not been limited to academic circles. In a 1985 meeting on responsibility contracts (both enterprise and agricultural) 
reports from 1982 on show that courts have been regularly resting their decisions on Economic Contract Law provisions. However, most court discussions of responsibility contract disputes state that the court refers to the Economic Contract Law for guidance but does not consider it controlling because responsibility contracts differ in certain ways from economic contracts. ${ }^{77}$ In this guiding role, then, the Economic Contract Law appears to have served two functions: First, it has furnished the judiciary with general principles of contract law, and second, it has provided specific rules for specific situations. ${ }^{78}$

One of the functions of the Economic Contract Law has been to provide a statutory basis for fundamental principles of contract law such as the binding nature of contracts and their legal enforceability. The first chapter of the Economic Contract Law enumerates a number of "general principles."

- Article 3 establishes that economic contracts must be in written form (except for contracts that are to be fulfilled immediately).

- Article 4 provides that the formation of economic contracts shall conform to state laws and accord with state policies and plans.

- Article 5 provides that the formation of economic contracts shall be based on the principle of equality, mutual benefit, agreement through consultation, and equal value of compensation, and that, furthermore, neither party shall impose its will on the other party, nor shall any unit or individual illegally interfere with contracts.

- Article 6 provides that economic contracts are legally binding once they are established, that parties shall fulfill their duties under the contract, and that neither party shall be allowed to terminate or modify contracts without authorization.

attended by economic trial judges, some individuals expressed the opinion that the contracts' specific contents, as long as they did not violate the principles of the Central Committee's Number 1 Documents, should be the sole legal basis for handling disputes. See Reference Materials on Economic Trial Work (1985), published and edited by the Supreme People's Court. No uncertainty over applicable procedural law has existed; courts have applied the Code of Civil Procedure. Some courts have noted, however, that the Code of Civil Procedure fails to cover the issue of how to treat responsibility contract partnerships procedurally, including the problem of one partner appearing in court purportedly on behalf of the partnership. These issues are dealt with in the 1986 Supreme Court Opinion on the handling of responsibility contract disputes. See text accompanying note 88 infra.

77. Unfortunately, courts do not elaborate on how their handling of responsibility contract disputes differs from their approach to economic contract disputes. One judge indicated in an interview that the court would take into account the household's obligation, as a subordinate subject of the collective, to obey collective directives regarding reasonable management of the contractedout land or resources.

78. See, for example, a report of the Jinzhou Intermediate Court of Liaoning Province stating that "in substantive law, during the time that the state has not formulated and promulgated regulations on agricultural production-linked contracts, . . . [our] administrative arbitration and judicial trial practice has shown that conscientiously implementing the basic principles and specific articles of the 'Economic Contract Law of the PRC' has been effective." 11 RESEARCH Materials, supra note 38 , at 11 . 
- Article 7 stipulates economic contracts that are invalid (wuxiao), or void ab initio. ${ }^{79}$

Courts have frequently rested their decisions on these general principles. For example, articles 5 and 6 have furnished courts with a firm statutory basis for enforcing contracts and imposing liability on parties who refuse to perform or unilaterally modify or terminate contracts. Court opinions in which courts decide to uphold contracts often cite these two articles. A typical example is a Zhejiang case where, after signing a peach orchard responsibility contract, collective leaders seized the revenues of the contracting peasants and also tried to raise the contract fee because they felt the peasants were becoming rich at the collective's expense. The peasant sued the leaders for breach of the contract. The court held that according to articles 5 and 6 of the Contract Law, economic contracts established in accordance with law were legally binding, both parties were obligated to completely perform their contract duties, and neither party could modify or terminate the contract at will. It thus ordered the leaders to return the seized funds and to honor the contract to the end of its three-year period. ${ }^{80}$

When confronted with rural responsibility contract disputes, one of the first analyses a court will make is whether the contract is a valid one that should be enforced. ${ }^{81}$ Article 7 of the Economic Contract Law routinely guides courts in this analysis; thus, courts determine if the contract violates laws or state policies, was induced through fraud or coercion, was signed by an agent who exceeded the scope of his authority, or violates state or public interest. Yet article 7 serves more as a starting point for judicial scrutiny of contracts than as a rigid rule; in their analyses, courts often also cite additional circumstances that will render a contract invalid, such as assignment of a contract by the contracting household without prior consent

79. Article 7. Chinese contract law theory does not appear to distinguish between void (invalid) contracts and voidable contracts. The Chinese term wuxiao hetong, at least as it is used in the Economic Contract Law, should be translated as void or invalid contract because the Law states that such contracts do not have any legal force from the moment they are made. See article 7.

80. See case reported in SHEN, supra note 60, at 19. See also id. at 22-23 for a similar case where peasants who were envious of a fellow villager's prosperity from the management of a brick kiln persuaded the team leader to drive the peasant away from the kiln, sell his car, and seize materials from the factory. The contracting peasant sued the team. The court ruled in favor of the peasant, finding that, since the contract accorded with the basic principles of the Economic Contract Law, it was legally binding and the team leader had unlawfully interfered with the autonomy and management rights granted by the contract to the peasant. See also id. at $\mathbf{4 0}$ for a similar case where the court upheld an apple orchard contract which collective leaders had unilaterally terminated. This case was made more complicated by the fact that the leaders had, with the approval of the township government, re-contracted out the orchard to another peasant following the attempted termination of the first contract. The second peasant had invested money in the care of the orchard and was on the verge of harvesting the apples. With these two facts in mind, the court helped negotiate a settlement under which: 1) the plaintiff agreed to let the third party continue management of the orchards for the year in progress and to keep profits from that year; 2) the plaintiff agreed to pay the third party 50 yuan as reimbursement for the care of some seedlings; 3 ) the plaintiff would reassume management of the orchard the year after; and 4) the plaintiff's original contract would be extended by a year. The editor of the book inserted this case to illustrate the point that the rights of innocent third parties should also be taken into consideration by courts. For a third example, see id. at 29.

81. See id. at 101-102. 
of the collective, use of the powers of political office to force the signing of a contract, use of powers of political office to obtain contracts with artificially low contract fees for friends and relatives, and contracting out without democratic discussion by the masses. ${ }^{82}$ In essence, courts have grafted policy considerations pertaining to responsibility contracts onto the analytical framework of the Economic Contract Law.

Courts have also referred to the Economic Contract Law for more narrow rules addressing specific issues. For example, courts have frequently based their decisions on the rules on responsibility for breach of contracts set forth in articles 32, 35, and 36. Article 32 states that liability for breach of economic contracts must be assumed by the party whose mistakes prevent partial or full contract performance; furthermore, where both parties have made mistakes, liability must be allocated between the parties according to the actual (specific) circumstances. In one case from a Beijing suburb, households who had contracted to manage vegetable plots sued their collective for allegedly reducing their production by failing to provide sufficient water in the first half of the year and flooding the crops during the second half of the year. Upon investigation, the court determined that the underwatering was a result of the households' own negligence. However, it also concluded that later crop losses were partially the fault of the collective, which had inadvertently flooded the households' lands twice. Citing article 32 , it refused to impose liability for losses incurred during the first part of the year on the collective but ruled that liability for the subsequent losses would be split between the households and the collective. ${ }^{83}$

Another provision of the Economic Contract Law governing modification and termination of contracts is article 28, which states: "Notices or agreements of the modification or termination of a contract should assume a written form (including a document or telegram)." On the basis of this provision, courts have refused to recognize oral modifications or terminations of contracts where the contents of the oral agreement cannot be proved. For example, in one case, an intermediate court annulled a lower court's ruling that had been based on the analysis that the defendant had not honored an oral agreement modifying the contract. In refusing to give legal effect to the oral agreement and finding that the original contract was still effective, the higher court cited article 28 's requirement that modification or termination be written. ${ }^{84}$

Article 31 concerning modification and termination of contracts has also been an important rule for the courts. Citing article 31 , which stipulates that "[a]fter an economic contract has been signed, it shall not be modified or terminated because the person involved in the signing or the legal

82. Interviews with judges of the Supreme Court and the Beijing Intermediate Court. See id.

83. The parties settled, with the collective agreeing to pay one-half of the losses incurred in the second half of the year and the households agreeing to pay the original contract fee in full. See id. at 20. For a court decision drawing on articles 32 and 35, see id. at 36-37.

84. A Judgment that Protects Contracting Parties Legal Rights and Interests, China Legal News, June 4, 1984 , at 3. But compare this case with one discussed infra at text following note 102. 
representative has been replaced," courts have disallowed leadership changes as a justification for unilateral abrogation of contracts. Many areas have experienced changes in the leadership of rural administrative organs in the wake of the dismantling of the commune system and its replacement with township governments, villagers' committees, and various types of cooperative economic organizations. ${ }^{85}$ One major cause of responsibility contract disputes has been the refusal of new leaders to honor contracts signed by their predecessors.

Courts have protected contracting parties against such contract breaches. For example, in one dispute that occurred in a village outside of Xining City in Qinghai Province, several peasants signed a contract to manage their village's brick factory. Two years into the contract, the brigade management committee was changed into a villagers' committee and new leaders were appointed. The new leaders decided to cancel the original contract and contracted out the factory to another party. After unsuccessful attempts by the township government and the district Bureau of Industrial and Commercial Administration to resolve the dispute, the peasants brought suit in the Xining Intermediate Court. The court ruled that the change in the committee name and leaders did not provide a ground for abrogating the original contract, found the second contract invalid, and ordered the return of the factory to the plaintiffs. It also directed that the committee compensate the plaintiffs for damages caused by the committee's freezing of the plaintiffs' accounts and assets (a total of 160,000 yuan) and ordered the current year's contract production quota be lowered since the dispute had halted production. Finally, it ruled that the fee for the suit, 1600 yuan, be paid by the defendant. ${ }^{86}$

2. Administrative Regulations. Responsibility contract disputes have occasionally centered on issues that are governed by administrative regulations. For example, in one case from Zhejiang, a dispute arose over the ownership of a sum of money paid by a state purchasing department to a contract household for sales of tea in excess of quota requirements. Both the contract household and its collective, the owner of the tea plantation that had been contracted out, claimed rights to the payment, which had been made under a state regulation providing for higher purchase prices and reduction in certain state-levied taxes when households exceeded production quotas. The responsibility contract between the household and the collective did not address the issue because the regulation had not existed at the time the contract was entered into.

The court determined that two sets of regulations, one promulgated by the provincial government and one by the provincial department of finance in

85. See note 59 supra.

86. See Peasant's Daily, February 26, 1986, at 1. See also Shen, supra note 60, at 114-115, and the Legal Advice Column in China Legal News, May 9, 1986, advising a peasant that his contract was protected by law from the attempts of new leaders to terminate it. 
conjunction with the provincial supply and marketing department, were relevant to the dispute. Guided by these administrative rules, it negotiated a settlement of the dispute. ${ }^{87}$ Although the account of this case does not mention the court's consulting with the provincial government and provincial departments, courts will typically discuss interpretation and application of administrative rules with the offices that promulgated them before rendering decisions.

3. Other Laws. Other laws that in some way bear on rural responsibility contracts-the General Principles, the Inheritance Law, and the land laws described above-were not cited either in case reports collected by the author or in court interviews. However, since most of the laws had been on the books for only a year or two at the time of many of the disputes analyzed in this article-the General Principles were not promulgated until 1986-lack of reference to the laws is not an indication that they will not serve as the basis for court decisions in the future. Unless a specific law or regulation on responsibility contracts is promulgated, the General Principles in particular may be frequently cited by courts since many of them are fundamental rules of broad-ranging application. For example, article 3, which establishes that parties in civil activities, whether legal persons or citizens, enjoy equal status, will give courts a legal basis for rejecting collective leaders' claims that their administrative authority over households grants them the power to terminate or modify contracts unilaterally. Similarly, articles 27 and 28 , which establish that the "contract management household" is a civil legal subject with independent rights and duties, will supply a statutory basis for the protection of the rights of contract households. ${ }^{88}$ But in terms of actual impact on the courts' resolution of disputes, the General Principles' contribution will be slight; as discussed above, the General Principles primarily reiterates adjudicatory principles that courts have been applying for several years already.

4. Other Legal Bases: Chinese Contract Law Theory and Supreme Court Guidelines on the Handling of Disputes. The Economic Contract Law did not create an entirely new set of contract law principles with one dramatic legislative stroke. Many fundamental principles of contract law, such as the binding nature and legal enforceability of valid contracts, the equal status of parties to a contract, and the requirement that contracts be modified or terminated only with the agreement of both parties, already had existed in the Chinese contract law theory explicated in textbooks and treatises. ${ }^{89}$ One commentator has argued that in the past, general provisions contained in treatises-along with statutes where these existed-guided the resolution of legal problems; for this reason, he argues that the new General Principles of Civil Law will have little actual effect,

87. See SHEN, supra note 60 , at 26

88. See Shen, Economic Trial Work and the General Principles of Civil Law 26, 32-33 (1987).

89. See, e.g., I Principles of Civil Law of the People's Republic of China 168-69, 184, $188-89$ (1980 China People's University Law Department, Civil Law Teaching and Research Group). 
being "for the most part a codification of the general provisions of the treatises." 90 Whether this view is entirely correct is debatable, but certainly the continuing influence of such basic principles is attested to by the occasional responsibility contract dispute decision in which the court enforces the contract and protects a party's contractual rights without reference to the Economic Contract Law or any administrative regulations.

For example, in one case involving a responsibility contract for the management of lotus fields, the collective lent its water pump to another village despite a contractual obligation to rent it to the contract household. The peasant subsequently suffered crop damage when heavy rains flooded his fields and the village failed to supply a pump. When he refused to pay the contract fee, the village sued him. The court did not cite the Economic Contract Law in its report of the case. Instead, it simply declared that it was necessary to protect firmly the "sanctity of contracts" (hetong de yansuxing) and the "legal rights and interests of contracting parties." It found that the village had violated the rights of the peasant and ordered the village to assume responsibility for breach of contract. 91

Greater uniformity in the courts' handling of disputes may come from a 1986 Supreme Court judicial document entitled "Opinion of the Supreme People's Court on Certain Problems in the Trying of Rural Responsibility Contract Disputes" ("1986 Opinion"). ${ }^{92}$ The 1986 Opinion, which is meant to guide lower courts in the handling of responsibility contract disputes, consists of eleven sections on the following issues: (1) court acceptance of the disputes; (2) determination of void contracts and the disposition of property in cases of void contracts; (3) assignment and subcontracting of contracts; (4) modification and termination of contracts; (5) release from, or reduction in, obligations in the event of natural disaster; (6) unilateral termination of contracts by the collective owner of the resources; $(7)$ overly high or low contract quotas; (8) exploitative management by contracting parties; (9) assumption of debts incurred to third parties during the contracting of township enterprises; (10) status of partnerships in litigation; and (11) the enforcement of judgments and settlements.

The 1986 Opinion belongs to the category of judicial documents that the Chinese term "judicial explanations" (sifa jieshi): formal commentary by China's highest organs of judicial work-the Supreme People's Court and the Supreme People's Procuracy-on specific problems concerning the application of laws that have arisen during adjudication or procuratorial work. ${ }^{93}$ Judicial explanations of the Supreme People's Court do not carry the

90. See Jones, Some Questions Regarding the Significance of the General Provisions of Civil Law of the People's Republic of China, 28 Harv. J. INT'L L. 309, 324-25 (1987).

91. Report of Yue Yin District Intermediate People's Court, 5 Legal System Monthly 12 (1985).

92. See 3 Bulletin of the Supreme People's Court 3 (September 20, 1986).

93. See Wu et al., Basic Theory of Chinese Socialist Law 261 (1987). According to Wu, the judicial explanations of the Supreme People's Court are termed "adjudication explanations" and those of the Supreme People's Procuracy termed "procuratorial explanations." Decisions of law that 
force of law-according to Chinese jurisprudential theory, courts do not make law-but are considered binding on lower courts unless special circumstances warrant otherwise. In the future, then, court approaches to responsibility contract disputes should become more uniform.

Unfortunately, it will not be possible to trace directly the 1986 Opinion's precise impact on the courts' handling of disputes because courts do not cite judicial explanations in their decisions even when decisions are based on them. Judges interviewed stated that the 1986 Opinion would aid in, but not dramatically alter, their handling of disputes since their current approaches were essentially consistent with those suggested in the Opinion. Such statements should not be regarded as simply self-serving; the Opinion is in fact the product of several judicial work conferences convened by the Supreme Court to discuss the handling of responsibility disputes, and it is likely that the results of those meetings were officially transmitted to courts. ${ }^{94}$

\section{Positions Taken by Local Governments or Administrative Organs Toward the Dispute}

One important factor in court decisionmaking which is usually not openly discussed by Chinese sources, and about which foreign students of the Chinese legal system know relatively little, is the position adopted by administrative organs or a local government toward a dispute. Because responsibility contract conflicts generally do not touch upon administrative regulations, administrative departments are not often approached by courts. Judicial solicitation of the opinion of an administrative department or local government is to be expected when there is a question of interpretation of an administrative rule; in many kinds of commercial disputes, administrative regulations can be decisive because relevant laws do not exist, contain lacunae, or are too general. However, the influence of local governments on judicial decisionmaking in responsibility contract disputes runs much deeper. Even though no administrative rules are involved, courts as a matter of course solicit the views of government officials and often place great weight on their opinions.

A case involving a contract to manage an orange grove in the suburbs of a large city ${ }^{95}$ gives some idea of this phenomenon. In this case, a peasant in a suburban collective organized a small group of friends and relatives that contracted to manage a grove of orange trees. As head of the group, the peasant signed with the collective a detailed responsibility contract to manage the trees for five years. Among other provisions, the contract required the

courts, including the Supreme People's Court, make in specific cases are not to be confused with judicial explanations; the former do not have any binding force beyond the immediate case and are not intended to guide future adjudications.

94. The Supreme Court organized at least two work conferences about responsibility contract disputes in 1985. Two of the main topics at the meetings were the criteria for void contracts and the administrative aspect of the contracts- the "superior/subordinate relationship" existing between the collective and the contracting party, who is usually a member of the collective.

95. Details of this case have been altered slightly for reasons of confidentiality. 
peasant to follow certain procedures for the care of the trees. Several months into the contract, the collective terminated the contract, charging that the peasant had violated it by selling fruit without permission, secretly retaining sales revenues instead of sharing them with the collective, and failing to care properly for the trees. The peasant sued the collective for breach of the contract.

The court commenced its investigation of the case by seeking out officials of the township government with jurisdiction over the collective. These officials informed the court that prior to the termination of the contract, government cadres from the city had decided that because fragmenting the large orange groves in the city's outlying counties and townships and contracting out parcels to individuals had resulted in poor management, the practice was to be halted. Instead, large groves were to be managed by special groups organized and coordinated by collectives. Furthermore, according to the officials, one of the city government cadres in charge of agricultural production had stated that large groves that had already been split up and contracted out to individual households should be reclaimed and contracted out anew to groups. In the opinion of the township officials, the collective's termination of the contract accorded with these decisions; the land involved in the dispute was part of a larger tract and the collective was not satisfied with its management. They had accordingly approved the collective's decision to seek to end the contract, ${ }^{96}$ and they continued to support that action. In response to the court's request to see written documentation of the city government policies, the township government cadres provided a document, issued by the "Fruit Products Production Leadership Group" of the city government; the document summarized comments made by city government officials at a recent meeting on proper management of suburban orange groves.

For the court, which on the basis of other evidence was already leaning towards the collective's position, the opinion of the township government officials and the city government document proved decisive. It adopted the position that while the collective had not done a proper job in explaining the situation to the peasant and persuading him early on to terminate the contract voluntarily, it did have the right to terminate the contract. After making its position clear to both parties, the court urged the plaintiff to withdraw the suit and accept a settlement with the collective. Under the proposed settlement, the contract would be terminated, but the collective, as acknowledgment that it had not approached the problem of terminating the contract properly and had not been sensitive to the peasant's concerns, would pay the peasant compensation for work missed because of the dispute. (All of the other members of the original contracting group had already accepted work

96. The collective apparently was not aware of the decisions of the city officials at the time it terminated the contract. 
assignments from the collective after the termination of the contract.) ${ }^{97}$ The court also informed the plaintiff that if he did not withdraw the suit, it would rule against him. The parties agreed to settle.

\section{The Principle of Fairness: Fairness in Contractual Dealings and Protection of Parties from Unforeseeable Economic Hardship}

Courts also are guided in their decisionmaking by a basic principle of fairness. No concept of party autonomy in contract formation, at least in the case of rural responsibility contracts, appears to restrain courts from achieving a just result by rewriting or terminating contracts. A prominent example is the courts' treatment of penalty (weiyuejin) clauses in contracts. When they exist, ${ }^{98}$ penalty clauses in contracts are usually directed against the contract household and may sometimes be onerous; one court reported seeing fish pond contracts calling for 50,000 to 60,000 yuan penalties where the total sum due under the contracts was a fraction of these amounts. ${ }^{99}$ Courts have refused to enforce penalty clauses they find "unreasonable," even where the contracting party has clearly breached the agreement.

Determination of what constitutes "unreasonable" is apparently decided by individual courts; courts stated they used their own judgment and made case-by-case determinations. The Zhengding County Court recounted two instances where it did not enforce penalty clauses; in one case, the penalty was 100 percent of the yearly contracting fee (2000 yuan) for late payment, and, in the other, a contract with a fee of 5000 yuan annual fee, the penalty was 1000 yuan for each day that payment of the contracting fee was overdue. ${ }^{100}$ The Yixing County Court stated that though it had not had disputes over penalty clauses, it would not enforce "unreasonable" penalties; in its opinion, the reasonableness of a penalty clause depended on the ability of the breaching party to pay compensation as well as the damages that the breach had caused or was likely to cause.

Courts also protect parties from losses when poor contract drafting enables one party to exploit loopholes in a contract. In one case handled by the Zhengding County Court, peasants from one village contracted to manage for one year the brick kiln of another village. The contract fee was 12,000 yuan. To run the kiln, the contract provided that "[o]ut of one ton of diesel oil stored in each warehouse, 150 gongjin will be supplied to the contracting party." When the peasants asked for the supply of oil, the other party refused

97. It is interesting to note that, originally, the judge in the case intended to rule that the termination of the contract was valid because the peasant had violated the conditions of the contract but nonetheless ordering the collective to pay the peasant some compensation owing to the collective's failure to educate the peasant on the necessity for ending the contract. However, after other judges of the court argued that such a decision was legally unsound, the court abandoned this approach and worked to arrange a settlement that would uphold the collective's position while granting the peasant some compensation.

98. Courts report that one of the most common deficiencies in contracts is the complete failure to provide for the possibility that one party may breach the agreement.

99. Interview with Yixing County Court, November 11, 1986.

100. Interview with Zhengding County Court, October 22, 1986. 
to provide any, on the grounds that it did not have any oil which was stored in warehouses. The peasants were able to purchase the necessary oil from outside sources but then refused to pay the contract fee at the year's end. The kiln owner sued for its contract fee. The court found that the kiln owner had deliberately drafted the clause on supplying oil in very specific language to permit it to avoid the spirit of the agreement; it did have oil, but the oil was not stored in warehouses. The court's solution was to negotiate a settlement under which the contract fee was reduced by 4000 yuan, roughly the amount the contracting party had expended on buying oil elsewhere. ${ }^{101}$

The courts' desire to see justice done, combined with an instrumental view of responsibility contracts that stresses performance and enforcement of contracts which further rural reform policies, has meant that they often discount the importance of legal formalities. Oral agreements for responsibility contracting have been common in the countryside. Generally, courts will enforce an oral agreement if both parties acknowledge the existence of the agreement and there is sufficient evidence proving its substance. ${ }^{102}$ One example is a 1985 Zhengding County case where the plaintiff, a villager, sued the villagers' committee for breach of a four-year orchard contract. The plaintiff alleged that the committee owed him money for produce which he had sold to it and had dispatched other villagers to occupy the orchards, thereby disrupting his production. According to the Zhengding County Court's investigation, two years into the contract the village committee had discovered that the villager was not taking care of the orchards' trees and had actually chopped down seven trees, acts that it felt violated the terms of the contract. The committee proposed to the villager that the contract be terminated early with some compensation paid to him, and the villager orally agreed to do so. Once the oral agreement was reached, the two sides commenced registration procedures for return of production equipment to the village; later, the committee also sent men to the orchards to take over its management. The court's investigation also revealed that the committee had not fully paid the villager for apples he had delivered under the contract and that it owed the villager money for vegetables which it had permitted the villager to plant in the orchard area.

Based on this investigation, the court was convinced that the parties had in fact reached an oral agreement and that pursuant to the agreement the village committee had dispatched men to the orchards. It thus ruled that the contract had been terminated through the mutual oral agreement of both parties. It added that the use of an oral rather than a written agreement to end the contract was incorrect; however, since the evidence showed that both sides had reached an agreement, it would uphold it. The decision concluded by

101. Though the Yixing County Court gave no specific examples, it also stated that it was prepared to declare a contract invalid if it found one party taking advantage of bad draftsmanship and if attempts to modify the contract through mediation were of no avail.

102. See SHEN, supra note 60, at 116-117. 
ordering the committee to pay the peasant the compensation it had promised him as well as the money owed for the apples and vegetables.

Another example is provided by a 1980 Shaanxi case. On appeal, the intermediate court found a contract valid despite the fact that the brigade's accountant had not affixed the collective's seal at the time of the contract's signing. The court reasoned that the contract should be considered valid because the leader who had signed it had publicly announced its validity and still recognized it; moreover, performance of the contract had already been underway for six months. ${ }^{103}$

Courts also consistently have acted out of a sense of fairness to protect parties from economic losses or burdens that are the result of unanticipated changes in state policies or regulations. In such situations, a court attempts to mediate a modification of the contract that takes into account the new policy or regulations. If it cannot persuade the parties to reach a new agreement, then it will terminate the contract. ${ }^{104}$ For example, in one case from Jiangsu, four households that specialized in raising ducks signed a two-year contract with their commune to raise 7000 ducks, but within a year had lost 27,000 yuan of the collective's money (apparently lent to the households as start-up capital) which the collective sued to recover. The court found that the households' losses had been caused by the termination of state subsidies for feed; at the time the contract was signed, state policy provided for subsidies, and the households had entered the subsidies into their calculation of the economics of the contract. Citing a provision in the Economic Contract Law that provides for termination or modification of contracts when performance by a party is rendered impossible due to external factors that are beyond the control of the party, ${ }^{105}$ the court determined that the loss was to be jointly assumed, and proceeded to mediate a settlement based on this principle. ${ }^{106}$

If courts believe that it is fair for unanticipated economic losses to be shared by contracting parties, they also appear to believe that unanticipated profits should likewise be shared by parties. Households holding orchard contracts reaped large profits in the mid-1980's with the decontrol of fruit prices. At least some courts perceive these profits to be windfall gains which perhaps should be shared with the collective and other villagers. ${ }^{107}$ In addition, courts are mindful of the Party policy stating that the responsibility system take care of not only individual but also state and collective interests. Thus, in orchard contract disputes arising out of complaints that it is unfair

103. "Compensation for Damages Should be Awarded When a Change in Cadres Causes Unilateral Abrogation of a Contract," unpublished summary of a dispute in Changan County, Shaanxi Province, in 1981.

104. See Shen, supra note 60, at 103 .

105. The court apparently was referring to article 27 of the Economic Contract Law. It should be noted that article 27 expresses only a general principle, viz., that contracts may be modified or terminated if one party is prevented from performance by external factors. It gives no specific guidance as to how contracts should be rewritten or how losses caused by external factors should be allocated between parties.

106. See SHEN, supra note 60, at 25-26.

107. Interview with Henan Province Higher Court judges; see also SHEN, supra note 60, at 105. 
for a single or a few households to enjoy the lion's share of the income from collective resources, courts are likely to try to persuade the contract household to accept a modification of its contract which would give the collective a larger contract fee or percentage of the sales income. ${ }^{108}$

\section{E. Summary: A Case Study}

The interaction of law, policy, and the court's sense of fairness can best be grasped by following from start to finish the handling of individual responsibility contract disputes. This article will therefore conclude with a closer look at one case.

The facts of this fascinating case, at least as stated in the report of the intermediate level court upon which this summary is based, ${ }^{109}$ are relatively simple. In early 1982, a production team which owned a machinery parts factory contracted it out to three individuals, one of whom, Zhang, was the team's leader. The three-year contract stated that the team would give no more than 2000 yuan to the contracting parties for equipment, that working capital would be supplied by the contracting parties, that each year the contracting parties would pay 1000 yuan to the team, and that after meeting the 1000 yuan payment the contracting parties would take a share of the profits.

In May 1982, Zhang called a meeting of the team's members. According to most witnesses at the meeting, he announced that the contract had been annulled and that the factory would be returned to the team for management. However, no written agreement stating that the contract had been annulled was produced at the meeting, and no notes of the meeting survived. Moreover, the original contract had not been torn up. After the meeting, the team assigned nine persons to work in the factory. Several months later, one of the three contracting individuals died and the second person withdrew from the contract, leaving Zhang as the only contracting party. Zhang appointed his older brother, an outsider from another village, to take charge of the factory. At that point, a dispute over control of the factory and division of its profits and assets erupted; the team sued Zhang, claiming that the contract had been terminated by the May meeting.

In July, the lower level court ruled that the contract was void because appointment of a non-team member to manage the factory violated its statement of purposes and thus exceeded the operating scope of its license. It

108. Henan Province Higher Court judges stated that they believed modification of contracts in these circumstances to be justified and fair but added that they would not force a household to agree to modification. Courts' readiness to modify contracts is attributable to political pressure as well as their own feelings of equity. Officials have expressed publicly the opinion that some patently "unreasonable" contracts should be "supplemented and perfected" to give the collective a larger cut of profits. See, e.g. Peasant's Daily, July 16, 1986, at 2.

109. In the interests of confidentiality, the location of the case has not been given and the type of factory altered. The case description is based on the court's unpublished report of the case to the local Party committee. However, the author did not have access to other materials or to the judges in the case. One suspects that the dispute was sparked or complicated by factors that the court's report does not mention. 
also ruled that the contract had lost legal effect after the May meeting. The court ruled that the factory's profits, fixed assets, original materials, and presently warehoused materials all belonged to the team. However, 10,000 yuan was to be taken out of the factory's profits to compensate Zhang. It also ordered Zhang to pay 70 percent, and the team 30 percent, of the litigation fee. Zhang appealed.

In December, after its efforts to reach a settlement collapsed, the intermediate court (the author of the report) convened a meeting of its trial committee (shenpan weiyuanhui). The committee was unable to reach a consensus. Some members felt the meeting had effectively rescinded the contract; others did not. The court then asked the provincial higher court for instructions. ${ }^{110}$ In December 1983, the court finally ruled that the contract had been terminated for two reasons: First, despite the fact that procedures for terminating the contract had not been completed, eleven out of the fifteen households in the team had acknowledged the contract's termination, and one of the original contracting individuals (the one who had withdrawn from the contract) had testified to that effect; and second, the original contracting subject, a group of three individuals, no longer existed. However, it found that the basic level court's decision that the contract was void was inappropriate. The intermediate court preserved most of the lower court's decision but modified it to make it slightly more favorable to Zhang, who was awarded the factory's original materials and the warehouse stock. The court also ordered each of the parties to pay 50 percent of the litigation fee.

The case did not end there, however. In April 1984, the local newspaper published a letter from Zhang complaining of his treatment. The letter was accompanied by a supportive investigative report. This publicity, together with letters from Zhang's lawyers to Party leaders at the Central Party Secretariat, the provincial committee, and the district committee, prompted the intermediate court formally to re-examine (fucha) its decision. The reexamination included discussions ${ }^{111}$ with the district and township Party

110. One of the issues raised by this case, and one about which foreign scholars have only impressionistic information, is the nature of the relationship between lower and higher courts. The court report uses the term qingshi, which is usually translated as "ask for instructions." The higher court's response is considered binding on the lower court. Unfortunately, because the court's report does not detail the higher court's answer, it is impossible to ascertain how it shaped the court's eventual decision.

111. Again, we can only speculate on the type of interaction between the court and the organizations with which it discussed the case. The report only describes the organizations' analyses of the case and provides few clues on the weight of those opinions. One heading of the report is entitled "Attitudes (taidu) of the District and Township Party Committees Toward the Case." Another heading is "Opinions of the Province Higher Court and the Rural Policy Research Section of the Provincial Committee." The report quotes the statement of the vice-president of the Province Higher Court to the head of the economic division that "[a]ll of our opinions are to be discussed with them [the judges from the intermediate court]. But we cannot impose a consensus." The report also quotes the head of the economic division as saying to the intermediate judges that " $[t]$ his is the opinion of the Province Economic Court. After returning, you (should) ask the trial committce to do research and report to the district committee for a decision." Although this implies that the district committee had the final say, it may be that the committee rarely changes a court 's recommendation. 
committees, the Province Higher Court, and the Rural Policy Research Section of the provincial committee.

The opinions offered by these groups are only summarized in the court's report. But even this partial glimpse provides an idea of the factors which influenced the court's final opinion. The opinions of the various groups show that debate focused on: 1) how policy should be applied to the case; and 2) the legal effect of the meeting. Opinions were divided on how policy influenced the case. Some felt that Zhang had to be supported and the decision changed on the basis of the 1984 Number 1 Document, which by firmly endorsing the contracting out of collective factories, even where the manager hired workers, ${ }^{112}$ was taken implicitly to mean that individuals who contracted to manage a factory should generally be supported. Others disagreed, stating that new policies should not be applied to a case already decided. Those who supported the decision also believed that the courts' awarding of 10,000 yuan to Zhang as compensation for his efforts met the spirit of the 1983 Number 1 Document. ${ }^{13}$ The Rural Research Policy Section cited both the 1983 and 1984 Documents as support for Zhang's hiring of his brother to manage the factory and suggested that his brother could not be regarded as a contracting party. Analyses on whether the meeting had terminated the contract or not were also split; many seemed to lean towards the view that though Zhang stated at the meeting that the contract had been ended, in fact, he and the team had not gone through the necessary legal procedures.

The court's own final opinion on how to resolve the case combines law, policy, and pragmatic considerations. It re-affirmed its previous conclusion that the contract was a valid one. But it changed its position regarding the meeting's legal effect on the contract; it now concluded that the meeting had been inconclusive and should not be regarded as terminating the contract. Noting that the factory had already resumed production under the management of the team, the court felt, however, that the proper method of handling the dispute was to have the contract terminated and to reward Zhang on a preferential basis as suggested in the 1984 Number 1 Document.

112. The 1984 Document gave strong approval to the contracting out of commune and brigade enterprises by stating that even where contracting parties (managers) hired workers, such operations should be considered part of the cooperative rather than private economy as long as management was carried out in accordance with certain principles. Those principles were: 1) ownership rights were to belong to the commune or brigade, sufficient funds reserved to cover the depreciation of fixed capital, and a certain proportion of funds set aside for the public accumulation fund; 2) a certain proportion of profit was to be turned over to the commune or brigade in accordance with regulations; 3) managers were to exercise full powers of management over the enterprise's business affairs, but only within the scope authorized by the commune or brigade; and 4) dividends were to be distributed to individual investors according to fixed proportions, and managers to be compensated "preferentially," as long as there was no excessively large disparity between their earnings and workers' incomes. Section 3, subsection 3, 1984 Number 1 Document.

113. The 1983 Document stated that collectives could experiment with contracting out of their factories and that managers should be compensated preferentially. See supra note 107. But its tone was more cautious than that of the 1984 Document. Furthermore, the 1983 Document emphasized that the responsibility system had to take into account the interests of state, collective, and individuals. Sep supra note 67. 
In the end, the court did not need to render a judgment; it was able to persuade the parties to accept a settlement that reflected the court's views. Zhang agreed to terminate the contract early while the team agreed to return the money in the factory's account that had been frozen at the start of the litigation. Money owed the team for back taxes, workers' wages, etc., was first to be deducted from the account. Fifty percent of the factory's net profit was to go the team, 30 percent to Zhang, and 20 percent to other investors in the factory. ${ }^{114}$ Finally, 70 percent of the litigation fee would be paid by the team and 30 percent by Zhang. ${ }^{115}$

\section{IV}

\section{ConClusion}

A number of different norms and sources of authority have guided Chinese judges in the adjudication of rural responsibility contract disputes. While these decisional guides have included laws and administrative regulations, many cases have actually been decided on the basis of other factors, most notably Party policy, the opinion of the local government, and a court's individual sense of justice and fairness in contractual dealings.

The judiciary's handling of rural responsibility contract disputes demonstrates how policy can deeply influerice court decisionmaking. Even assuming diminished Party involvement in judicial work, the unchallenged political leadership of the Party ensures that Party policy will continue to be an important consideration in court deliberations. Though distinct in theory, the lines between law and policy blur when courts apply policy guidelines, sometimes in conjunction with legal rules, sometimes independently, to resolve disputes. The equation of policy to legal rules which courts have a duty to enforce is revealed by the courts' occasional reference to policies of the Party and the government as "policy regulations" (zhengce guiding).

The dominant role of Party policy in agricultural responsibility contract disputes can be attributed to the confluence of two factors-the absence of governing laws and regulations and the Party's close, sustained involvement

114. The settlement does not mention the 10,000 yuan that was to be paid to Zhang under the first two decisions. Although it is not clear, it appears that Zhang was not paid this sum because the settlement yielded him more than 10,000 yuan.

115. The Zhang factory dispute indicates how it may be almost impossible for outside observers to determine from the case opinion or mediation settlement alone the actual complexity of a case; the mediation settlement negotiated by the parties makes no reference to the policy or legal issues that made the case such a thorny one to decide. It is unlikely that a court decision would have mentioned these issues either. Indeed, we can assume that although most of the case's key issues have been revealed to us by the intermediate's court report to the county committee, there are also some that have not. One aspect that we do not really see through the court's report is the personal conflicts that must have colored the case and may have been at the root of the dispute. From the circumstances of the case that we know through the court report, it seems likely that the dispute was caused by the envy of at least some of the team leaders for Zhang's success with the factory. The report does not provide us with any clues as to the nature of the relations between the judges of the two courts that ruled on the case and the parties. However, according to Chinese lawyers with litigation experience, personal relations between a judge and a party may influence, to varying degrees, the court's eventual disposition of a case. 
in the responsibility system reform. The role of policy in economic disputes should thus diminish whenever two conditions exist: First, there are laws or regulations governing the issues in controversy, and second, there are no specific Party policies concerning those issues. When both of these conditions are met, courts can be expected to decide disputes primarily by applying the controlling legal rules, perhaps after consulting administrative departments.

But another possibility exists. It may be that there are governing laws or regulations as well as relevant Party policies. If this is the case, what happens when the laws and policies conflict? In years past, particularly during the Cultural Revolution, when "bourgeois law" and formal legal institutions came under heavy attack, there was no question that law was subordinate to policy. Since 1978, however, rejecting such assertions of the supremacy of politics over law, some Chinese legal scholars have argued that law should take precedence over policy when the two conflict. ${ }^{116}$ The courts' handling of responsibiliy contract disputes suggests, however, that outside of the academic text, law currently remains subordinate to policy: When Party policy called for adjustment of contracts, courts have been willing to terminate valid contracts to effectuate policy.

Court adjudication of responsibility contract disputes has not been only a matter of law and policy. Judicial decisionmaking also has been based on the opinions of local government officials. Deference to local government bureaucrats-who, especially in rural areas, often wear a second hat as local Party leaders-is a reflection of the political realities of Chinese society. In comparison to the dominant institution of the Party and the powerful Chinese state bureaucracy, the judiciary wields little or no power. Even as court officials decry "administrative interference" in valid responsibility contracts, they acknowledge the ability of government officials to hinder unjustifiably or to block totally performance of contracts. Thus, courts, particularly lower level ones, frequently defer to the views of government officials or attempt to fashion solutions to disputes endorsed by local officials; without such support, enforcement of judgments, especially against collectives, can be extremely difficult. Consultation of government bureaucrats, at least in responsibility contract cases, appears to be commonplace; consultation is certainly not limited to instances in which a court requires interpretation or clarification of an administrative regulation or Central Committee policy.

Judicial deference to local governments may not be purely a characteristic of rural responsibility contract adjudication, but may be part of a more general phenomenon of judicial deference to state organs which have administrative jurisdiction over the disputants, the subject matter of the contract, or the specific issue in controversy. Courts trying disputes involving urban enterprises will often discuss the dispute with the administrative agency or agencies with supervisory authority over the enterprises. In cases where there do not appear to be any laws or regulations applicable to the issues in

116. See, for example, the response to a question about why cadres were also targeted by the effort to popularize basic legal knowledge. China I.egal System News, August 12, 1986, at 3. 
dispute, courts may even refuse to decide a dispute until an administrative office has declared its position toward the matter. In one dispute observed by the author in Beijing, a court initially accepted a dispute that erupted between two units when one worker from the first unit who had been temporarily loaned to the second unit under a contract was killed, and others injured, in an accident while working for the second unit. Both parties denied responsibility for the accident and sought to have the other pay compensation to the victim's family and to assume medical, disability, and other expenses for the injured individuals. Faced with a dispute that did not appear to be covered by any contract or labor regulations, the court informed the parties that it would not take any action until the local labor bureau reached a decision on the proper handling of the matter. Since the labor bureau refused to get involved in the dispute-on the grounds that the contract between the units was not a labor contract or governed by regulations on workmen's compensation-the court has repeatedly put off rendering a decision.

Though not articulated as such by courts, the basic principle of fairness in contractual relations clearly forms an important basis for court decisionmaking. In responsibility contract disputes, the courts' sense of equity has led to the rewriting of contracts when it appears one party has knowingly taken advantage of the other, when parties' inexperience in contract drafting results in patently inequitable arrangements, and when parties suffer economic losses due to unforeseeable market changes. That same sense of fairness appears to underlie court willingness to push for modifications of contracts when one party profits from windfall gains. To some extent, court willingness to adjust contract terms in responsibility contract disputes may be based on the relative commercial naivete of both peasants and the leaders of their collectives as well as both groups' inexperience with the use and drafting of contracts. Future studies of judicial handling of contract disputes involving more commercially and legally sophisticated enterprises and individuals should provide a useful comparison.

\section{ADDENDUM}

Much of the research for this article was completed by the end of 1986 . Since that time, the number of rural responsibility contract disputes in Chinese courts has declined, both in absolute terms and as a percentage of total economic contract disputes. Two facts account for the drop in the number of cases: First, courts have increasingly referred the disputes to relevant administrative departments; and second, there appear to be fewer conflicts between households and collective cadres over the contracts. Voluntary readjustment of contracts by households and collectives to better reflect the production and income potential of contracted-out resources, negotiation of new contracts which avoid the mistakes of the earliest contracts 
(such as vagueness and overly low contract fees), and, in some areas, more even distribution of production income owing to the return of high income production resources such as apple orchards to collective management have all helped to reduce the number of conflicts.

With the shake-out period of rural responsibility contracts apparently over and disputes less frequent, information on judicial resolution of disputes has become more scarce. There is no cause to believe, however, that the courts' methods of deciding disputes they have accepted have changed significantly. Legal rules remain only one of several decisional bases, and the legal framework governing the contracts remains skeletal: As of 1989, regulations governing the contracts were still mired in the drafting stage. Worth special attention, though, is how courts are deciding disputes that are appearing as a result of an agricultural policy, introduced several years ago but not yet widespread, of "appropriate-scale management" (shidu guimo jingying)-recentralization of land management in an attempt to increase production efficiency. Specifically, appropriate-scale management calls for the reconcentration of scattered, small plots of land that had previously been contracted out to individual households into much larger parcels; these large parcels are entrusted to either the collective, a group of households that operate as a collective unit, or one household with proven success in grain production, for management. Although official and academic discussions of appropriate-scale management stress that previously contracted-out land should not be reclaimed from peasants against their will, rural cadres in some areas have unilaterally annulled responsibility contracts and reassigned land over peasants' objections, triggering disputes. ${ }^{117}$ As of 1989, reconcentratica and re-contracting of land was proceeding unevenly in different parts of the country and was being most aggressively pursued in developed, prosperous areas. But due to peasant reluctance to give up land, weak rural organization in some areas, and the lack of strong incentives for asserting collective control (such as highly profitable production resources or the availability of farm machinery), re-collectivization had not affected much of the countryside.

The events of spring 1989 are unlikely to directly influence the courts' handling of rural responsibility contract disputes. The killing of hundreds of innocent citizens in the name of suppressing a "counter-revolutionary rebellion" amounts neither to a one-blow dismantling of the Chinese legal system nor a repudiation of the importance of legal institutions and rules. But it is a tragic and chilling reminder to people in and outside of China that the Party's will and word still reign supreme. Furthermore, in a reversal of the trend prior to June 4, a now highly insecure Party has decided to assert anew the leadership role of the Party in judicial matters. ${ }^{118}$ Thus, if Party leaders in

117. See, e.g., the reports of disputes in Shunyi County outside of Beijing in People's Daily, June 3, 1988, at 2; June 18, at 2; and Oct. 26, at 2 .

118. Ren Jianxin, President of the Supreme People's Court, declared at a conference on judicial work in January 1990 that "various levels of the people's courts must accept, of their own accord, 
[Vol. 52: No. 3

charge of agricultural policy determine that some degree of re-collectivization is the route for hundreds of millions of peasants in the 1990's (and as of early 1990, this does appear to be their conclusion), it will be an exceptional judge indeed who does not uphold a unilateral termination or modification of existing rural responsibility contracts made in the name of that policy.

Party leadership" and that "it is a mistake to think that because there is the law, justice can be executed without the guidance of the Party." 